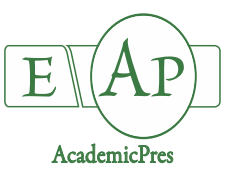

Ciulca S et al. (2020)
Notulae Botanicae Horti Agrobotanici Cluj-Napoca 48(3):1369-1386
DOI: $10.15835 /$ nbha48312019
Research Article

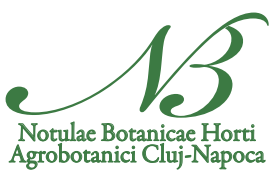

\title{
Grain size and other agronomical traits variation in a winter wheat population of doubled haploid lines
}

\author{
Sorin CIULCA ${ }^{1}$, Aurel GIURA ${ }^{2}$, Adriana CIULCA ${ }^{1 *}$ \\ ${ }^{1}$ Banat's University of Agricultural Sciences and Veterinary Medicine "King Michael I of Romania" Timisoara, 119 Calea Aradului, \\ 300365, Timisoara,_Romania;c_i_sorin@yahoo.com; adrianaciulca@gmail.com (*corresponding author) \\ ${ }^{2}$ National Agricultural Research and Development Institute Fundulea, 915200 Fundulea, Calarasi, Romania; agiura@ricic.ro
}

\begin{abstract}
In wheat, the size of the grain, respectively its dimensions as well as degree of filled, are important characteristics on which depends both the weight of the grain and yield of flour, the quality of milling and baking as well as the production capacity of the respective genotype. This paper presents the results obtained by studying for three years, under field condition, 85 doubled haploid (DH) lines obtained from the F1's of 'G.603-86' (large grains genotype) × 'F.132' (normal grains genotype) crosses using biotechnological Zea system. The environmental conditions of the three years had an important contribution on the genotype $\times$ year interaction, which showed also a higher influence on 1000 kernel weight (TKW). The variability of plant height and ear emergence data was also affected to a similar extent by this interaction. Based on the performed results and analyses, were highlighted lines which show high and stable values of TKW (54-64 g), associated with a plants height of approximately $85-100 \mathrm{~cm}$ and an ear emergence from May 11 to 17, under some climatic conditions similar to the period of study. These doubled haploids lines can be considered as promising genotypes for using in wheat breeding programs in order to improve yield performances under temperate continental climate conditions.
\end{abstract}

Keywords: DH lines; flowering date; plant height; stability; TGW; wheat

\section{Introduction}

In wheat, the grain size respectively its dimensions as the degree of filling are important characteristics depending upon both the weight of the grain and the yield of the flour respectively the quality of the milling. Being also considered to be components of production with highest phenotypic stability, these attributes have been and remain constant concerns of breeding programs. Several studies argue that the progress of selection for a superior production capacity is directly related to the gradual increase of the grain size and degree of filling. Recently results based on eight years tests in different Southeast European countries including Romania with 422 prospective wheat lines and new varieties originated from the main wheat grown globally areas highlight the importance of 1000 kernel weight (TKW) and volumetric mass (VM) in achieving high production (Sharma et al., 2014).

Undoubtedly, similar advances have been made in other breeding programs, given the importance of these attributes in expressing the productivity of newly created varieties. As a result, searches for identifying 
new sources for TKW and VM have been recently become targets of real interest in breeding and genetic studies even at the molecular level.

It should be mentioned that genotypes with higher values for TKW and for the grain shape and size were also obtained by using mutagenic procedures with physical and chemical mutagens (Cheng et al., 2015; Zhang et al., 2015; Dobre and Giura, 2016). Also, in related species among which Triticum spelta and Aegilops tauschii squarrosa were identified in their hybrid progeny with common wheat forms with superior values for the grain size and grain weight (Giura, 2010; Xie et al., 2015).

The first genetic analysis of grain size, their dimensions and the degree of grain filling in wheat, have stated a complex genetic determinism by genes located on the majority of chromosomes and this in relation with the other plant morphology and physiological attributes. There were also identified the chromosomes involved in controlling specific traits, the same or different ones from one genotype to another (Law, 1967; Petrovici and Worland, 1968; Halloran, 1976; Chojeki et al., 1983; Snape et al., 1985; Giura and Săulescu, 1996). Subsequently, through molecular analysis, molecular markers/QTL's associated with some of these attributes have also identified capitalizing that the required information can provide new chances for the creation of varieties with superior productivity (Börner et al., 2002; Ramya et al., 2010; Cui et al., 2011; Simmonds et al., 2014; Li et al., 2019; Ma et al., 2019).

One of the new sources of grain size is also the autumn wheat line 'G.603-86' obtained at National Agricultural Research and Development Institute (NARDI) Fundulea from the cross 'Cologna lunga' $\times$ 'F.6-

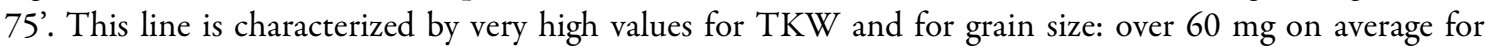
several years and a grain length of 8.5-9.0 mm. Genetic analysis based on F3 disomics, cytologically extracted for each chromosome from the F2 monosomic populations ('Favorit'-monosomics $\times$ 'G.603-86') revealed a complex genetic control exerted by several chromosomes: some with positive effects, other with negative effects on weight, size and degree of grain filling (Giura and Săulescu, 1996).

However, in practical breeding this complex genetic determinism can impedes to a great extent, the transfer of the respective attributes by using classical methods without to use specific molecular markers, during selection cycles. In addition, the line 'G.603-86' of $90-93 \mathrm{~cm}$ height carries $R h t B 1 b$ and $R h t D 1 b$ loci and consequently in the crosses with genotypes carrying $R h t B 1 b$ and/or $R h t D 1 b$ can appear even higher forms due to allelic difference at $P p d D I$ loci. The line also shows sensitivity to some foliar diseases, especially to yellow rust and brown rust as well a clear flowering and maturity delay compared to current varieties better suited to local growing conditions. In addition, in some years, the line exhibits a substantial strain elongation due probably to the presence in genome of a different other genes for photoperiod and vernalization requirements. Probably these attributes are inhered from the 'Cologna lunga' genitor originated from a local Italian old wheat population with unknown genealogy but with a presumptive ascendance in the Triticum turgidum sp. (Giura, 2010).

Doubled haploid (DH) production has been successfully used in breeding and genetic analysis of qualitative and quantitative traits in wheat. The main advantage of DH technology consists in the considerable reduction of time necessary to obtain homozygous lines (Ren et al., 2015; Patial et al., 2019), which is an important breakthrough to speed up the cultivar development programs (Dunwell, 2010). In wheat, haploids can be mainly produced by in vitro androgenesis and interspecific crosses with: maize, related species to maize (Zea mays L. spp. Mexicana, Tripsacum dactyloides); sorghum Sorghum bicolor), pearl millet (Pennisetum glaucum); Job's tears (Coixlachryma-jobi) (Mochida and Tsujimoto, 2001). High ploidy level and the $\mathrm{D}$ genome of wheat have an important role in $\mathrm{DH}$ production, using wide hybridization with maize (Niu et al., 2014).

This paper presents and discusses the data for 2004, 2005 and 2016 regarding plant height, ear emergency and thousand kernel weights. The aim of this paper is to identify DH lines with higher TKW values indifferently of environmental conditions, with a similar vegetative period and plant height as modern Romanian cultivars. 


\section{Materials and Methods}

\section{Biological material and experimental design}

For a more comprehensive analysis of the complexity of genetic control of the grain size, grain dimensions and their connection to other plant traits, we developed using the Zea system a mapping population of $85 \mathrm{DH}$ lines. For this purpose, line 'F.603-86' was crossed with the breeding line 'F.132' with small grains but carrying the RhtB1b and RhtDla genes for plant height control, Lr34 and Lr67 genes for brown rust resistance and a vegetative period corresponding to local conditions, being earlier with about 1012 days compared to 'G.603-86' line. The F1 hybrids were then crossed by maize in greenhouse condition and haploid plants regenerated by in vitro culture of immature embryos. Regenerated plantlets were treated with colchicine to obtain doubled haploid $(\mathrm{DH})$ lines.

The resulted $85 \mathrm{DH}$ lines and parental forms were then studied at NARDI Fundulea in a field trial in 2004, 2005 and 2016 years respectively, using a randomized block design with three replications. The average monthly temperatures and rainfall in Fundulea, during the period of study are presented in Figure 1. The genotypes where sown in pair rows of $1 \mathrm{~m}$ long, spaced apart at $25 \mathrm{~cm}$ between rows and $50 \mathrm{~cm}$ between pairs. Plant height was measured from the soil level to the top of the spike, without awns, using ten plants / replicate for each genotype. Ear emergence date was recorded when $50 \%$ of the spikes from each plot had visible awns, and counted as number of days after/before 1 May. At maturity, 30 spikes (10 spikes/plot) were randomly selected and harvested for each DH line and parental form. The TKW was estimated by weighing the quantity of the seeds per each spike and divided by seed number.

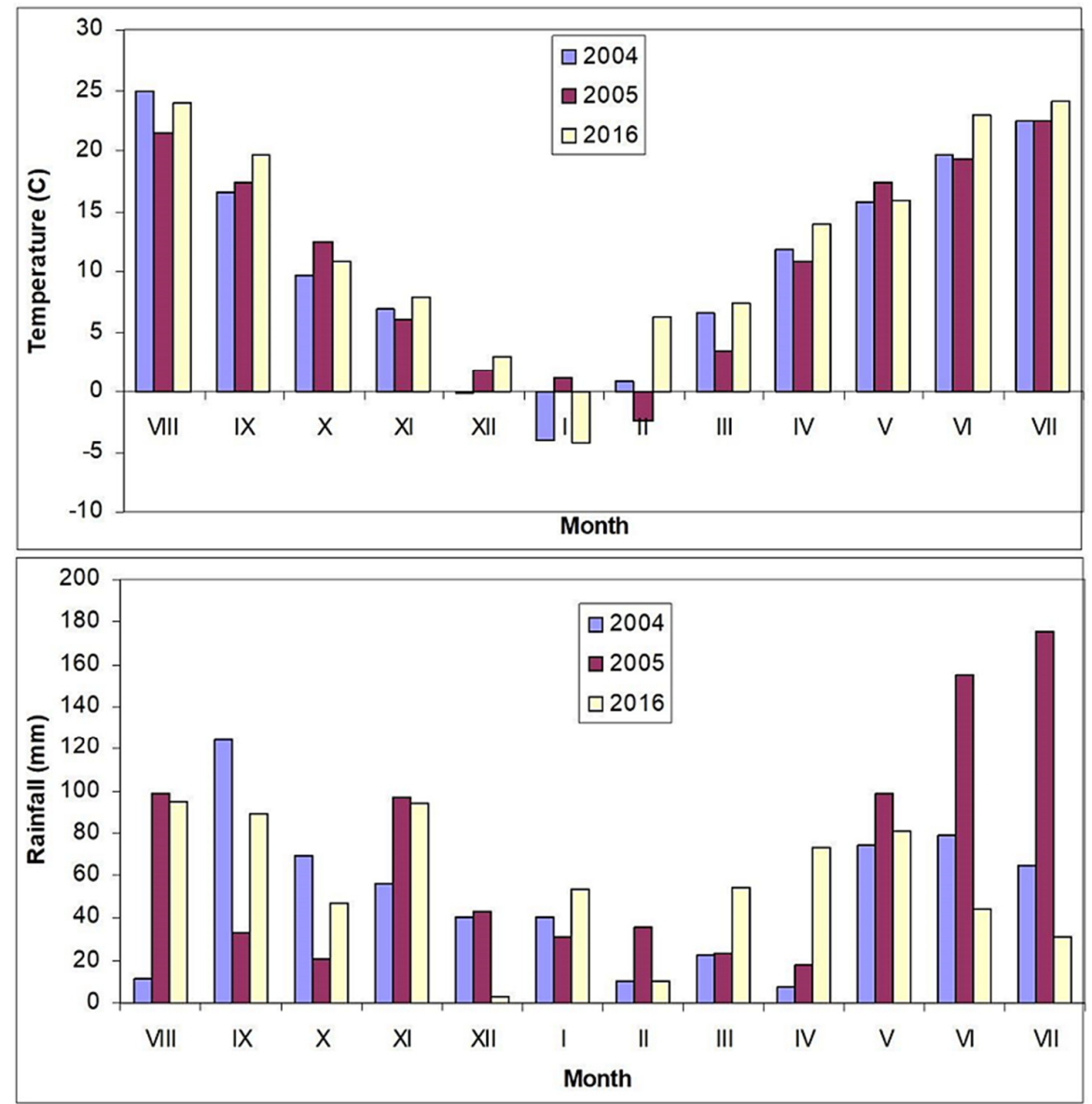

Figure 1. Average monthly temperatures and rainfall in Fundulea during 2004-2005 and 2016 


\section{Statistical analysis}

The data collected for plant height, ear emergence date and TKW were statistically processed by combined ANOVA and AMMI analysis using MATMODEL Version 3. The means for each trait were compared using Multiple Range Test (Ciulca, 2006). The significance of differences between means was presented based on letters, being considered as significant the differences between means marked with different letters ( $\mathrm{a}, \mathrm{b}, \mathrm{c}-$ for genotype $\times$ years comparisons; $\mathrm{A}, \mathrm{B}, \mathrm{C}$ - for years comparisons).

The AMMI stability value (ASV) was calculated as previously described by Purchase et al. (2000). It represents the distance to the origin of each line in a two-dimensional space based on interaction principal component axis 1 (IPCA1) and interaction principal component axis 2 (IPCA2) coordinates, considering that lower ASV indicate higher stability.

\section{Results}

The combined analysis of the variance based on the AMMI 2 model for wheat genotypes over three years (Table 1) indicates that both genotype and climatic conditions, respectively their interaction had significant effects on TKW. The genotype showed the highest influence $(64.24 \%)$ on the variability of this trait, followed by genotype $\times$ year interaction $(28.46 \%)$, amid lower influence $(7.3 \%)$ of climatic conditions during the study period. The high contribution of the genotype to the variation of the TKW indicates the existence of major differences between wheat genotypes. This model based on the first two principal components fully expresses the effect of genotype $\times$ year interaction on this trait. As such, it's relevant to assess the stability of TKW for wheat genotypes based on the first two principal components.

Table 1. Combined analysis of variance according to the AMMI 2 model for TKW of wheat genotypes

\begin{tabular}{|c|c|c|c|c|c|}
\hline Source of variation & SS & DF & MS & F & SS $\%^{1}$ \\
\hline Total & 52418 & 782 & & & 64.24 \\
\hline Genotype & 30822 & 86 & 358.40 & $42.13^{* *}$ & 7.30 \\
\hline Year & 3503 & 2 & 1751.44 & $205.87^{* *}$ & $9.33^{* *}$ \\
\hline Genotype $\times$ Year & 13651 & 172 & 79.37 & $28.46(100)$ \\
\hline IPCA 1 & 8634 & 87 & 99.24 & $11.84^{* *}$ & 63.24 \\
\hline IPCA 2 & 5018 & 85 & 59.03 & $7.04^{* *}$ & 36.76 \\
\hline IPCA residuals & 0 & 0 & & & \\
\hline Error & 4441 & 522 & 8.51 & & \\
\hline
\end{tabular}

1 - \% of model sum of squares for genotype, year, and genotype $\times$ year; ${ }^{* *}$ significant at $P \leq 0.01$.

Based on the data from Table 2 it is noted that generally the climatic conditions of 2005 have favoured the achievement of significantly higher values of this trait, while in 2016 the values of TKW were lower than other years. Under the conditions from $2004 \mathrm{TKW}$ recorded values between $25.6 \mathrm{~g}$ at ' $\mathrm{DH}$ 6-27' and $66.4 \mathrm{~g}$ at 'DH 5-10', amid a relatively symmetrical distribution of genotypes: $9.20 \%$ with values over $60 \mathrm{~g} ; 37.93 \%$ with values of $50-60 \mathrm{~g} ; 40.23 \%$ with values of $40-50 \mathrm{~g} ; 12.64 \%$ with values below $40 \mathrm{~g}$. This year the lines 'DH 5-10', 'DH 6-7' and 'DH 5-11' were highlighted, which achieved a TKW of over $65 \mathrm{~g}$.

Given the conditions of 2005 the wheat genotypes showed smaller amplitude of this trait, with the limits from $34.5 \mathrm{~g}$ at ' $\mathrm{DH}$ 6-27' to $68 \mathrm{~g}$ at ' $\mathrm{DH}$ 6-7', associated with the following distribution: $13.79 \%$ of the lines with TKW over $60 \mathrm{~g} ; 33.33 \%$ with values of $50-60 \mathrm{~g} ; 50.57 \%$ with values of $40-50 \mathrm{~g} ; 2.30 \%$ with TKW below $40 \mathrm{~g}$. The amplitude of TKW in 2016 was close to that recorded in 2005, amid lower values ranging from $27.7 \mathrm{~g}$ to $62.6 \mathrm{~g}$ ' $\mathrm{DH}$ 6-12', and 'G 603/86'. Thus, the distribution of genotypes showed a clear left asymmetry: only $2.30 \%$ of genotypes with TKW over $60 \mathrm{~g} ; 28.74 \%$ with values of $50-60 \mathrm{~g} ; 43.68 \%$ with values of 40-50 g; 25.29\% with values below $40 \mathrm{~g}$. Next to line 'G 603/86', only line 'DH 6-31' achieved an TKW over $60 \mathrm{~g}$. Regarding the annual values of TKW (Table 1), it is found that about $20 \%$ of the lines did 
not show significant variations during the study, while for $5.75 \%$ of the lines, the TKW differ significantly from one year to another.

Table 2. Values of TKW for wheat genotypes in 2004, 2005 and 2016

\begin{tabular}{|c|c|c|c|c|c|c|c|c|c|c|c|c|c|}
\hline No. & Genotype & 2004 & 2005 & 2016 & Mean & ASV & No. & Genotype & 2004 & 2005 & 2016 & Mean & ASV \\
\hline P1 & G 603/86 & $60.5 a$ & $64.0 \mathrm{a}$ & $62.6 a$ & 62.4 & 0.404 & 45 & DH 6-20 & $46.4 \mathrm{~b}$ & $66.2 \mathrm{a}$ & $43.3 b$ & 51.9 & 1.113 \\
\hline P2 & F 132 & $40.9 a$ & $41.2 \mathrm{a}$ & $33.1 \mathrm{~b}$ & 38.4 & 0.301 & 46 & DH 6-21 & $55.2 \mathrm{ab}$ & $57.8 \mathrm{a}$ & $51.4 \mathrm{~b}$ & 54.8 & 0.081 \\
\hline 3 & DH 5-1 & $44.2 \mathrm{a}$ & $48.5 a$ & $47.2 \mathrm{a}$ & 46.6 & 0.457 & 47 & DH 6-22 & $45.4 \mathrm{a}$ & $46.7 \mathrm{a}$ & $36.4 b$ & 42.8 & 0.437 \\
\hline 4 & DH 5-2 & $46.2 \mathrm{a}$ & $43.6 a$ & $43.9 \mathrm{a}$ & 44.6 & 0.333 & 48 & DH 6-23 & $64.8 \mathrm{a}$ & $60.7 \mathrm{a}$ & $52.3 \mathrm{~b}$ & 59.3 & 0.578 \\
\hline 5 & DH 5-3 & $44.3 \mathrm{a}$ & $40.7 \mathrm{a}$ & $39.7 \mathrm{a}$ & 41.5 & 0.265 & 49 & DH 6-24 & $36.9 \mathrm{~b}$ & $41.4 \mathrm{a}$ & $37.8 \mathrm{~b}$ & 38.7 & 0.292 \\
\hline 6 & DH 5-4 & $43.0 \mathrm{~b}$ & $48.7 \mathrm{a}$ & $50.5 a$ & 47.4 & 0.782 & 50 & DH 6-25 & $52.7 \mathrm{a}$ & $49.0 \mathrm{a}$ & $51.4 \mathrm{a}$ & 51.0 & 0.459 \\
\hline 7 & DH 5-5 & $47.0 \mathrm{a}$ & $41.9 \mathrm{~b}$ & $48.1 \mathrm{a}$ & 45.7 & 0.717 & 51 & DH 6-26 & $49.6 a$ & $44.6 \mathrm{ab}$ & $39.1 \mathrm{~b}$ & 44.4 & 0.437 \\
\hline 8 & DH 5-6 & $50.7 a$ & $49.3 \mathrm{ab}$ & $44.7 \mathrm{~b}$ & 48.2 & 0.153 & 52 & DH 6-27 & $25.6 b$ & $34.5 a$ & $30.3 a$ & 30.1 & 0.535 \\
\hline 9 & DH 5-7 & $47.3 \mathrm{a}$ & $46.7 \mathrm{a}$ & $48.7 \mathrm{a}$ & 47.5 & 0.510 & 53 & DH 6-28 & $52.4 \mathrm{a}$ & $50.4 a$ & $39.7 \mathrm{~b}$ & 47.5 & 0.632 \\
\hline 10 & DH 5-8 & $39.0 \mathrm{c}$ & $61.5 \mathrm{a}$ & $49.6 b$ & 50.0 & 1.070 & 54 & DH 6-29 & $54.7 b$ & $61.5 \mathrm{a}$ & $56.3 b$ & 57.5 & 0.344 \\
\hline 11 & DH 5-9 & $48.7 \mathrm{a}$ & $47.9 \mathrm{a}$ & $34.6 \mathrm{~b}$ & 43.7 & 0.788 & 55 & DH 6-30 & $56.6 a$ & $52.7 \mathrm{a}$ & $35.8 \mathrm{~b}$ & 48.4 & 1.231 \\
\hline 12 & DH 5-10 & $66.4 a$ & $55.5 b$ & $50.2 c$ & 57.4 & 0.800 & 56 & DH 6-31 & $54.5 b$ & $48.0 \mathrm{c}$ & $60.3 a$ & 54.2 & 1.154 \\
\hline 13 & DH 5-11 & $65.6 a$ & $60.6 b$ & $59.0 \mathrm{~b}$ & 61.7 & 0.301 & 57 & DH 6-32 & $61.1 \mathrm{a}$ & $60.4 a$ & $44.2 b$ & 55.2 & 1.014 \\
\hline 14 & DH 5-12 & $35.1 \mathrm{~b}$ & $52.9 \mathrm{a}$ & $48.6 \mathrm{a}$ & 45.5 & 1.101 & 58 & DH 6-33 & $47.5 \mathrm{a}$ & $55.1 \mathrm{a}$ & $40.3 b$ & 47.6 & 0.613 \\
\hline 15 & DH 5-13 & $50.9 a$ & $50.2 a$ & $40.2 b$ & 47.1 & 0.511 & 59 & DH 6-34 & $45.7 \mathrm{~b}$ & $44.1 \mathrm{~b}$ & $51.5 \mathrm{a}$ & 47.1 & 0.910 \\
\hline 16 & DH 5-15 & $41.7 \mathrm{a}$ & $44.7 \mathrm{a}$ & $42.4 \mathrm{a}$ & 42.9 & 0.307 & 60 & DH 6-35 & $51.7 \mathrm{a}$ & $47.1 \mathrm{a}$ & $48.3 a$ & 49.0 & 0.382 \\
\hline 17 & DH 5-17 & $45.8 \mathrm{a}$ & $47.2 \mathrm{a}$ & $44.3 \mathrm{a}$ & 45.8 & 0.176 & 61 & DH 6-36 & $45.4 \mathrm{a}$ & $46.7 \mathrm{a}$ & $47.6 \mathrm{a}$ & 46.5 & 0.493 \\
\hline 18 & DH 5-18 & $53.1 \mathrm{a}$ & $46.6 b$ & $47.8 \mathrm{~b}$ & 49.1 & 0.413 & 62 & DH 6-37 & $52.1 \mathrm{~b}$ & $60.7 \mathrm{a}$ & $54.1 \mathrm{~b}$ & 55.6 & 0.393 \\
\hline 19 & -19 & $48.6 \mathrm{a}$ & $51.7 \mathrm{a}$ & $41.2 b$ & 47.1 & 88 & 63 & 38 & $2 \mathrm{a}$ & $53.7 \mathrm{ab}$ & $49.1 \mathrm{~b}$ & 52.6 & 161 \\
\hline 20 & DH 5-20 & $56.4 a$ & $44.9 b$ & $58.5 \mathrm{a}$ & 53.2 & 1.161 & 64 & DH 6-39 & $52.4 \mathrm{a}$ & $53.1 \mathrm{a}$ & $45.4 b$ & 50.3 & 0.254 \\
\hline 21 & DH 5-21 & $61.9 a$ & $66.2 a$ & $47.1 \mathrm{~b}$ & 58.4 & 1.044 & 65 & DH 6-40 & $46.7 \mathrm{~b}$ & $49.8 \mathrm{ab}$ & $52.5 \mathrm{a}$ & 49.7 & 0.720 \\
\hline 22 & DH 5.22 & $37.8 \mathrm{c}$ & $57.8 \mathrm{a}$ & $50.2 b$ & 48.6 & 1.068 & 66 & DH 6-41 & $46.9 \mathrm{~b}$ & $47.1 \mathrm{~b}$ & $54.4 a$ & 49.4 & 0.968 \\
\hline 23 & DH 5-23 & $55.9 a$ & $56.6 a$ & $48.3 \mathrm{~b}$ & 53.6 & 0.303 & 67 & DH 6-42 & $57.2 \mathrm{a}$ & $55.2 \mathrm{a}$ & $50.7 \mathrm{~b}$ & 54.4 & 0.186 \\
\hline 24 & $\mathrm{DH}$ & $49.0 \mathrm{~b}$ & $56.9 \mathrm{a}$ & $38.9 \mathrm{~b}$ & 48.3 & 36 & 68 & 43 & $48.9 b$ & $54.4 \mathrm{a}$ & $52.1 \mathrm{ab}$ & 51.8 & 0.446 \\
\hline 25 & -26 & $38.3 \mathrm{a}$ & $40.2 \mathrm{a}$ & $32.8 \mathrm{~b}$ & 37.1 & 76 & 69 & 44 & $4 \mathrm{a}$ & $49.5 \mathrm{~b}$ & $51.8 \mathrm{~b}$ & 52.9 & 0.486 \\
\hline 26 & DH 5-27 & $50.8 \mathrm{a}$ & $51.5 \mathrm{a}$ & $39.4 \mathrm{~b}$ & 47.2 & 0.615 & 70 & DH 6-45 & $56.6 a$ & $50.6 \mathrm{~b}$ & $48.5 b$ & 51.8 & 0.359 \\
\hline 27 & DH 6-1 & $58.1 \mathrm{a}$ & $57.2 \mathrm{a}$ & $59.5 \mathrm{a}$ & 58.3 & 0.518 & 71 & DH 6-46 & $41.9 b$ & $49.3 \mathrm{a}$ & $52.4 \mathrm{a}$ & 47.8 & 0.974 \\
\hline 28 & DH 6-3 & $52.8 \mathrm{a}$ & $52.3 \mathrm{a}$ & $55.5 a$ & 53.5 & 0.609 & 72 & DH 6-47 & $57.2 \mathrm{a}$ & $54.6 \mathrm{a}$ & $42.6 \mathrm{~b}$ & 51.5 & 0.772 \\
\hline 29 & DH 6-4 & $49.7 \mathrm{a}$ & $48.8 \mathrm{ab}$ & $45.0 \mathrm{~b}$ & 47.8 & 0.107 & 73 & DH 6-48 & $52.2 \mathrm{a}$ & $47.6 \mathrm{~b}$ & $48.8 b$ & 49.5 & 0.380 \\
\hline 30 & DH 6-5 & $46.7 \mathrm{a}$ & $44.2 \mathrm{a}$ & $42.4 \mathrm{a}$ & 44.4 & 0.210 & 74 & DH 6-49 & $48.7 \mathrm{~b}$ & $53.9 \mathrm{a}$ & $40.3 c$ & 47.6 & 0.572 \\
\hline 31 & DH 6-6 & $62.3 a$ & $63.5 \mathrm{a}$ & $57.3 \mathrm{~b}$ & 61.0 & 0.103 & 75 & DH 6-50 & $50.0 \mathrm{a}$ & $50.9 \mathrm{a}$ & $41.4 b$ & 47.4 & 0.386 \\
\hline 32 & DH 6-7 & $66.3 a$ & $68.0 \mathrm{a}$ & $59.3 \mathrm{~b}$ & 64.5 & 0.290 & 76 & DH 6-51 & $51.7 \mathrm{a}$ & $48.3 \mathrm{a}$ & $47.1 \mathrm{a}$ & 49.0 & 0.254 \\
\hline 33 & DH 6-8 & $46.2 \mathrm{a}$ & $44.8 \mathrm{a}$ & $38.3 \mathrm{~b}$ & 43.1 & 0.269 & 77 & DH 6-52 & $52.5 \mathrm{a}$ & $53.6 \mathrm{a}$ & $45.3 b$ & 50.5 & 0.286 \\
\hline 34 & DH 6-9 & $30.8 \mathrm{~b}$ & $42.9 \mathrm{a}$ & $32.8 \mathrm{~b}$ & 35.5 & 0.513 & 78 & DH 6-53 & $53.5 b$ & $62.8 \mathrm{a}$ & $40.4 \mathrm{c}$ & 52.2 & 1.152 \\
\hline 35 & DH 6-10 & $45.9 \mathrm{a}$ & $44.4 \mathrm{a}$ & $30.9 b$ & 40.4 & 0.832 & 79 & DH 6-55 & $39.0 \mathrm{~b}$ & $41.1 \mathrm{~b}$ & $46.3 \mathrm{a}$ & 42.1 & 0.881 \\
\hline 36 & DH 6-11 & $47.0 \mathrm{~b}$ & $53.9 \mathrm{a}$ & $33.6 c$ & 44.8 & 1.055 & 80 & DH 6-56 & $43.7 \mathrm{~b}$ & $45.2 b$ & $50.6 a$ & 46.5 & 0.864 \\
\hline 37 & DH 6-12 & $38.5 \mathrm{a}$ & $39.8 \mathrm{a}$ & $27.7 \mathrm{~b}$ & 35.3 & 0.583 & 81 & DH 6-59 & $55.8 \mathrm{a}$ & $57.4 \mathrm{a}$ & $56.3 a$ & 56.5 & 0.335 \\
\hline 38 & DH 6-13 & $45.9 a$ & $45.0 \mathrm{a}$ & $42.9 \mathrm{a}$ & 44.6 & 0.182 & 82 & DH 6-60 & $52.8 \mathrm{a}$ & $54.1 \mathrm{a}$ & $53.9 a$ & 53.6 & 0.397 \\
\hline 39 & DH 6-14 & $48.5 \mathrm{a}$ & $46.2 \mathrm{ab}$ & $43.1 b$ & 45.9 & 0.174 & 83 & DH 6-61 & $53.1 \mathrm{a}$ & $53.6 \mathrm{a}$ & $42.5 \mathrm{~b}$ & 49.7 & 0.542 \\
\hline 40 & DH 6-15 & $41.5 \mathrm{~b}$ & $44.7 \mathrm{ab}$ & $47.6 \mathrm{a}$ & 44.6 & 0.740 & 84 & DH 6-64 & $58.1 \mathrm{a}$ & $59.4 a$ & $36.3 b$ & 51.3 & 1.497 \\
\hline 41 & DH 6-16 & $54.4 a$ & $47.4 \mathrm{~b}$ & $48.6 \mathrm{~b}$ & 50.1 & 0.424 & 85 & DH 6-65 & $44.6 \mathrm{a}$ & $44.3 \mathrm{a}$ & $37.2 \mathrm{~b}$ & 42.0 & 0.258 \\
\hline 42 & DH 6-17 & $30.6 \mathrm{~b}$ & $46.6 a$ & $44.0 \mathrm{a}$ & 40.4 & 1.087 & 86 & DH 6-66 & $43.1 \mathrm{a}$ & $41.5 \mathrm{a}$ & $33.7 b$ & 39.4 & 0.381 \\
\hline 43 & DH 6-18 & $52.3 \mathrm{a}$ & $51.7 \mathrm{a}$ & $38.6 \mathrm{~b}$ & 47.5 & 0.752 & 87 & DH 6-67 & $49.1 \mathrm{~b}$ & $48.0 \mathrm{~b}$ & $56.3 a$ & 51.1 & 1.003 \\
\hline 44 & DH 6-19 & $39.7 b$ & $44.9 \mathrm{a}$ & $38.0 \mathrm{~b}$ & 40.8 & 0.182 & \multicolumn{2}{|r|}{ Mean } & 49.3B & $50.7 \mathrm{~A}$ & $45.7 \mathrm{C}$ & 48,6 & \\
\hline
\end{tabular}


Depending on the values of the ASV parameter (Table 2), it is noted that the highest stability of the TKW was presented by the lines: 'DH 6-21', 'DH 6-6', 'DH 6-4', 'DH 5-6', 'DH 6-38', 'DH 6-14', 'DH 526, 'DH 5-17', 'DH 5-26', 'DH 6-13', 'DH 6-19'. The high stability of lines 'DH 6-6', 'DH 6-21' and 'DH 638 ' was also associated with high levels of TKW, over $52 \mathrm{~g}$.

Considering that the IPCA1 axis expresses approximately $63.24 \%$ of the genotype $\times$ year interaction from Figure 2 it is observed that the highest values of TKW were registered under the conditions from 2004-2005, while in 2016 the values were considerably lower. Also, according to the coordinates of each year it turns out that the conditions from 2016 showed a higher contribution to the genotype $\times$ year interaction, compared to those from 2004-2005.

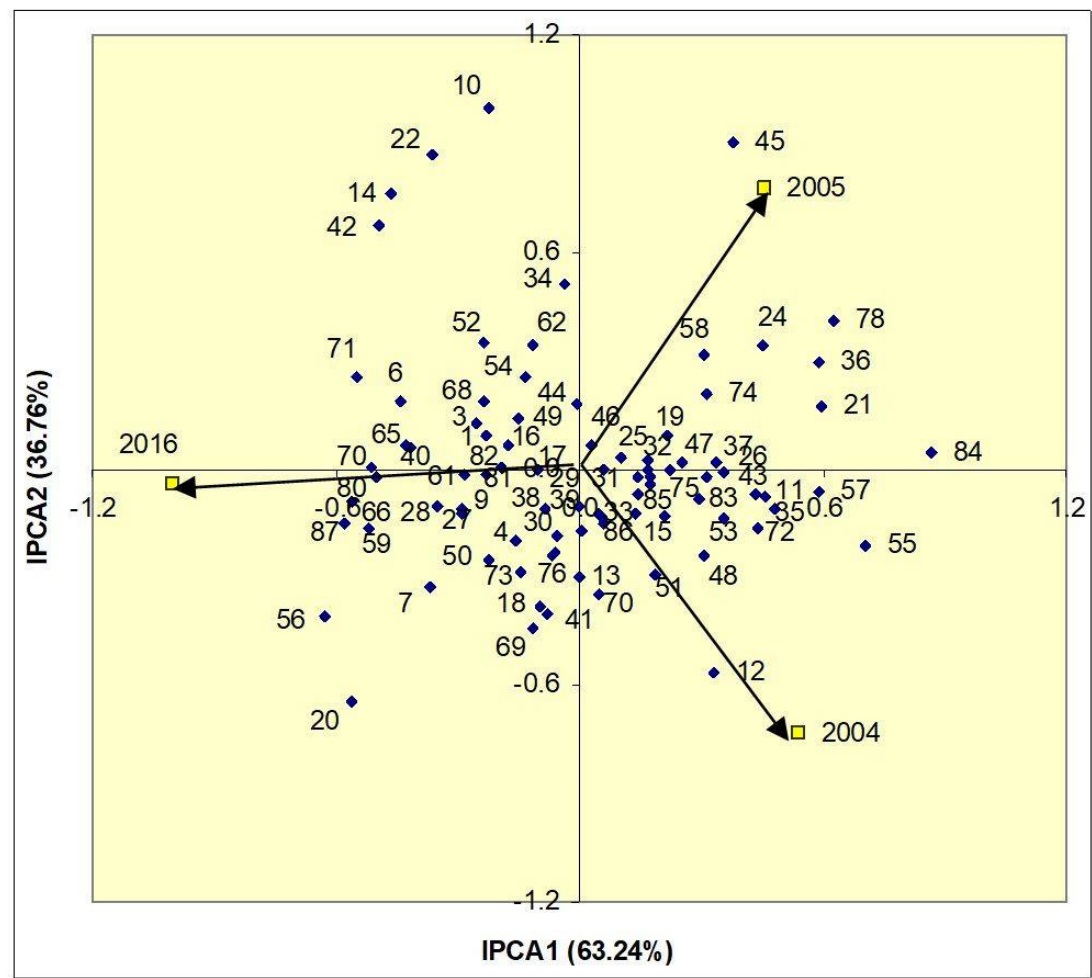

Figure 2. Biplot of interaction for principal component axis (IPCA1 and IPCA2) for TKW of wheat genotypes during 2004-2005 and 2016

The genotypes close to the vector of a given year indicate a strong association with this one. Thus, the line 'DH 6-20' showed a specific adaptation to the conditions of 2005 when it registered a TKW significantly higher with 20-23 g compared to other years. Also, the line 'DH 5-10' showed a strong specific adaptation to the conditions of 2004, achieving a significantly higher TKW by 11-16 g compared to the values of 2005 and 2016.

In case of lines: 'DH 6-21', 'DH 6-6, 'DH 6-4', 'DH 5-6', 'DH 6-38', the close position to the origin indicates high stability of TKW. Considering the distance from the origin, from Figure 2 it is observed that the lines 'DH 6-64', 'DH 6-30' and 'DH 6-53' shows a low stability associated with high values of TKW under the conditions from 2004-2005 and significantly lower values in 2016. For lines 'DH 6-31' and 'DH 5-20', the high instability is associated with a significantly lower TKW in 2005 compared to the values of 2004 and 2016 . The lines 'DH 5-8', 'DH 5-12', 'DH 5.22', 'DH 6-17', presented a high interaction with the climatic conditions during the study, recording different values of this trait from year to year, higher in 2005 and lower in 2004. 
According to the analysis of the variance based on the first two components of the interaction (Table 3 ), it is found that all three main sources of variation had a significant influence on plant height of wheat genotypes during the three years. For this trait, the contributions of the three sources of variation are more balanced, so that the variability of plant height was influenced to a high extent by the genotype (49.88\%), while the genotype $\times$ year interaction had a lower influence (16.03\%). Given that the first two main components fully express the effect of genotype $\times$ year interaction, it turns out that the AMMI 2 model is suitable for the assessment of plant height at this set of genotypes.

Table 3. Combined analysis of variance according to the AMMI 2 model for plant height

\begin{tabular}{|c|c|c|c|c|c|}
\hline Source of variation & SS & DF & MS & F & SS ${ }^{1}$ \\
\hline Total & 200941 & 782 & & & \\
\hline Genotype & 98870 & 86 & 1150 & $6466.58^{* *}$ & 49.88 \\
\hline Year & 67560 & 2 & 33780 & $220.08^{* *}$ & 34.08 \\
\hline Genotype $\times$ Year & 31783 & 172 & 185 & $35.37^{* *}$ & $16.03(100)$ \\
\hline IPCA 1 & 25347 & 87 & 291 & $55.92^{* *}$ & 79.75 \\
\hline IPCA 2 & 6435 & 85 & 76 & $14.53^{* *}$ & 20.25 \\
\hline IPCA residuals & 0 & 0 & & & \\
\hline Error & 2727 & 522 & 5 & & \\
\hline
\end{tabular}

1 - \% of model sum of squares for genotype, year and genotype $\times$ year; ${ }^{* *}$ significant at $P \leq 0.01$.

The climatic conditions during the study showed a strong influence on plant height, causing significant variations from year to year (Table 4). Thus, the conditions from 2016 were significantly more favourable for increasing the plants height compared to those of 2004-2005. The amplitude of the plant height for wheat lines in 2004 was $53.5 \mathrm{~cm}$, ranging from $45.5 \mathrm{~cm}$ in 'DH 6-27' to $99 \mathrm{~cm}$ in 'DH 6-23'. Thus, the distribution of genotypes showed a low asymmetry with the following structure: only $16.09 \%$ of the lines with a plant height below $60 \mathrm{~cm} ; 14.94 \%$ with values of $60-70 \mathrm{~cm} ; 32.18 \%$ with values of $70-80 \mathrm{~cm} ; 27.59 \%$ with values of $80-90 \mathrm{~cm} ; 9.2 \%$ of the lines with a plant height over $95 \mathrm{~cm}$.

Under the conditions from 2005 the plants height recorded values between $100 \mathrm{~cm}$ in 'DH 6-23' and $46.3 \mathrm{~cm}$ in 'DH 6-27', on the background of a left asymmetry of the genotypes distribution: $12.64 \%$ of the genotypes with a height of plants over $90 \mathrm{~cm} ; 31.03 \%$ with values of $80-90 \mathrm{~cm} ; 27.59 \%$ with values of $70-80$ $\mathrm{cm} ; 14.94 \%$ with values $60-70 \mathrm{~cm} ; 13.79 \%$ with a height below $60 \mathrm{~cm}$. Also, and this year lines 'DH 6-23' and 'DH 6-29' showed the highest plant $(99-100 \mathrm{~cm})$.

Given the conditions of 2016, there was a considerable increase of plants height for all genotypes. The amplitude of this trait $(68 \mathrm{~cm})$ was higher than the previous years, ranging from $59.5 \mathrm{~cm}$ in 'DH 6-12' to $127.5 \mathrm{~cm}$ in 'DH 5-10' and 'DH 5-20'. The distribution of genotypes in this year showed a left asymmetry, with the following structure: $13.79 \%$ of genotypes with a plant height over $110 \mathrm{~cm} ; 22.99 \%$ with values of $100-110 \mathrm{~cm} ; 26.44 \%$ with values of $90-100 \mathrm{~cm} ; 20.69 \%$ with a values of $80-90 \mathrm{~cm} ; 10.34 \%$ with values of 70 $80 \mathrm{~cm}$; only five genotypes have had a height below $70 \mathrm{~cm}$. Higher values of plant height of over $120 \mathrm{~cm}$ were recorded this year by the lines: 'DH 5-10', 'DH 5-20', 'DH 6-29', 'DH 6-21', 'DH 5-11', 'DH 6-23'.

Considering the annual averages of plants height, it is observed that lines ' $\mathrm{F} 132$ ', 'DH 6-33' and 'DH 6-60' did not registered significant variations during the study. Most lines $(78.16 \%)$ have better used the conditions from 2016, showing significantly higher plant compared to 2004-2005. About $15 \%$ of the lines have a very different reaction to the conditions during the study, recording significant differences of plant height from year to year.

According to ASV parameter (Table 4), it is noted that the highest stability was recorded by the lines: 'DH 6-24', 'G 603/86', 'DH 6-31', 'DH 6-39', 'DH 6-42', 'DH 6-23', 'DH 5-3', 'DH 6-28'. The good stability of these lines was associated with a high size of plants at 'DH 6-23' (106.5 cm), 'G 603/86' (98.17 $\mathrm{cm})$ and 'DH 6-42' $(90.22 \mathrm{~cm})$, and with lower values at 'DH 6-28' $(65.50 \mathrm{~cm})$ and 'DH 5-3' $(72.67 \mathrm{~cm})$, respectively. 
Table 4. Values of plant height for wheat genotypes in 2004, 2005 and 2016

\begin{tabular}{|c|c|c|c|c|c|c|c|c|c|c|c|c|c|}
\hline No. & Genotype & 2004 & 2005 & 2016 & Mean & ASV & No. & Genotype & 2004 & 2005 & 2016 & Mean & ASV \\
\hline $\mathrm{P} 1$ & G 603/86 & $92.5 \mathrm{~b}$ & $90.5 b$ & $111.5 \mathrm{a}$ & 98.2 & 0.098 & 45 & DH 6-20 & $90.0 \mathrm{~b}$ & $73.5 \mathrm{c}$ & $104.0 \mathrm{a}$ & 89.2 & 0.578 \\
\hline P2 & F 132 & $75.0 \mathrm{a}$ & $76.3 a$ & $77.0 \mathrm{a}$ & 76.1 & 1.776 & 46 & DH 6-21 & $87.5 \mathrm{~b}$ & $88.0 \mathrm{~b}$ & $125.5 a$ & 100.3 & 1.749 \\
\hline 3 & DH 5-1 & $73.5 b$ & $75.0 \mathrm{~b}$ & $92.0 \mathrm{a}$ & 80.2 & .187 & 47 & DH 6-22 & $63.5 \mathrm{~b}$ & $64.7 \mathrm{~b}$ & $76.0 \mathrm{a}$ & 68.1 & 0.752 \\
\hline 4 & DH 5-2 & $53.0 \mathrm{~b}$ & $52.0 \mathrm{~b}$ & $67.5 a$ & 57.5 & 0.459 & 48 & ) 6-23 & $99.0 \mathrm{~b}$ & $100.0 \mathrm{~b}$ & $120.5 \mathrm{a}$ & 106.5 & 0.128 \\
\hline 5 & DH 5-3 & $68.0 \mathrm{~b}$ & $64.0 \mathrm{c}$ & $86.0 \mathrm{a}$ & 72.7 & 0.156 & 49 & DH 6-24 & $61.0 \mathrm{~b}$ & $63.0 \mathrm{~b}$ & $82.5 \mathrm{a}$ & 68.8 & 0.084 \\
\hline 6 & DH 5-4 & $88.5 \mathrm{~b}$ & $90.5 b$ & $104.0 \mathrm{a}$ & 94.3 & 0.502 & 50 & DH 6-25 & $85.0 \mathrm{~b}$ & $86.3 b$ & $110.0 \mathrm{a}$ & 93.8 & 0.451 \\
\hline 7 & DH 5-5 & $54.0 \mathrm{~b}$ & $55.3 \mathrm{~b}$ & $76.5 a$ & 61.9 & 0.209 & 51 & DH 6-26 & $79.5 \mathrm{~b}$ & $80.0 \mathrm{~b}$ & $92.5 \mathrm{a}$ & 84.0 & 0.672 \\
\hline 8 & DH 5-6 & $80.0 \mathrm{~b}$ & $78.5 \mathrm{~b}$ & $100.5 \mathrm{a}$ & 86.3 & 0.169 & 52 & DH 6-27 & $45.5 b$ & $46.3 \mathrm{~b}$ & $60.0 \mathrm{a}$ & 50.6 & 0.542 \\
\hline 9 & DH 5-7 & $71.0 \mathrm{~b}$ & $74.0 \mathrm{~b}$ & $98.5 \mathrm{a}$ & 81.2 & 0.616 & 53 & DH 6-28 & $58.5 \mathrm{~b}$ & $60.5 b$ & $77.5 \mathrm{a}$ & 65.5 & 0.164 \\
\hline 10 & $\mathrm{DI}$ & $79.5 \mathrm{~b}$ & $80.5 \mathrm{~b}$ & $107.0 \mathrm{a}$ & 89.0 & 0.709 & 54 & H 6-29 & $96.5 b$ & $99.0 \mathrm{~b}$ & $126.5 \mathrm{a}$ & 107.3 & 0.880 \\
\hline 11 & $5-9$ & $80.5 b$ & $84.5 a$ & $4.0 \mathrm{ab}$ & 83.0 & 1.760 & 55 & -30 & $83.5 \mathrm{~b}$ & $85.5 \mathrm{ab}$ & $87.5 \mathrm{a}$ & 85.5 & 1.614 \\
\hline 12 & DH 5-10 & $91.0 \mathrm{~b}$ & $92.0 \mathrm{~b}$ & $127.5 \mathrm{a}$ & 103.5 & 1.580 & 56 & DH 6-31 & $70.0 \mathrm{~b}$ & $71.3 \mathrm{~b}$ & $91.5 \mathrm{a}$ & 77.6 & 0.112 \\
\hline 13 & DH 5-11 & $77.5 \mathrm{c}$ & $87.5 \mathrm{~b}$ & $124.0 \mathrm{a}$ & 96.3 & 2.137 & 57 & DH 6-32 & $79.5 \mathrm{~b}$ & $81.5 \mathrm{~b}$ & $109.0 \mathrm{a}$ & 90.0 & 0.855 \\
\hline 14 & DH 5-12 & $56.5 \mathrm{~b}$ & $57.3 \mathrm{~b}$ & $72.5 \mathrm{a}$ & 62.1 & 0.397 & 58 & DH 6-33 & $82.5 \mathrm{a}$ & $84.0 \mathrm{a}$ & $77.5 b$ & 81.3 & 2.462 \\
\hline 15 & DH 5-13 & $79.0 \mathrm{~b}$ & $80.3 \mathrm{~b}$ & $95.0 \mathrm{a}$ & 84.8 & 0.421 & 59 & DH 6-34 & $62.5 b$ & $64.0 \mathrm{~b}$ & $96.0 \mathrm{a}$ & 74.2 & 1.266 \\
\hline 16 & -15 & $67.5 c$ & $74.0 \mathrm{~b}$ & $92.5 \mathrm{a}$ & 78.0 & 0.261 & 60 & & $57.5 \mathrm{~b}$ & $59.0 \mathrm{~b}$ & $92.5 \mathrm{a}$ & 69.7 & 1.411 \\
\hline 17 & DH 5-17 & $74.0 \mathrm{~b}$ & $72.0 \mathrm{~b}$ & $98.5 \mathrm{a}$ & 81.5 & 0.568 & 61 & DH 6-36 & $72.5 \mathrm{c}$ & $79.0 \mathrm{~b}$ & $106.5 \mathrm{a}$ & 86.0 & 1.088 \\
\hline 18 & -18 & $74.0 \mathrm{c}$ & $87.5 \mathrm{a}$ & $80.0 \mathrm{~b}$ & 80.5 & 2.002 & 62 & 37 & $87.5 \mathrm{~b}$ & $88.7 \mathrm{~b}$ & $97.5 \mathrm{a}$ & 91.2 & 0.994 \\
\hline 19 & DH 5-19 & $61.5 \mathrm{~b}$ & $74.0 \mathrm{a}$ & $77.0 \mathrm{a}$ & 70.8 & 1.057 & 63 & DH 6-38 & $69.5 \mathrm{~b}$ & $70.7 b$ & $101.0 \mathrm{a}$ & 80.4 & 1.088 \\
\hline 20 & DH 5-20 & $72.5 \mathrm{~b}$ & $61.5 \mathrm{c}$ & $127.5 \mathrm{a}$ & 87.2 & 3.958 & 64 & DH 6-39 & $76.0 \mathrm{~b}$ & $77.3 \mathrm{~b}$ & $97.5 \mathrm{a}$ & 83.6 & 0.112 \\
\hline 21 & DH 5-21 & $88.0 \mathrm{~b}$ & $73.5 \mathrm{c}$ & $104.5 \mathrm{a}$ & 88.7 & 0.603 & 65 & -40 & $81.5 \mathrm{~b}$ & $83.0 \mathrm{~b}$ & $100.0 \mathrm{a}$ & 88.2 & 0.187 \\
\hline 22 & & c & $\mathrm{b}$ & $0 \mathrm{a}$ & 83.7 & 2 & 6 & & $\mathrm{~b}$ & $\mathrm{~b}$ & $d_{d}$ & .7 & 175 \\
\hline 23 & & $81.0 \mathrm{a}$ & $56.5 \mathrm{~b}$ & $5 \mathrm{a}$ & 74.0 & 67 & 67 & & $33.5 b$ & $7 \mathrm{~b}$ & $02.5 \mathrm{a}$ & 0.2 & 122 \\
\hline 24 & DH 5-25 & $70.0 \mathrm{c}$ & $81.0 \mathrm{~b}$ & $87.5 \mathrm{a}$ & 79.5 & 0.793 & 68 & DH 6-43 & $71.0 \mathrm{~b}$ & $72.0 \mathrm{~b}$ & $95.0 \mathrm{a}$ & 79.3 & 0.370 \\
\hline 25 & DH 5-26 & $62.5 \mathrm{~b}$ & $64.0 \mathrm{~b}$ & $86.0 \mathrm{a}$ & 70.8 & 0.298 & 69 & DH 6-44 & $72.5 \mathrm{~b}$ & $74.0 \mathrm{~b}$ & $96.5 \mathrm{a}$ & 81.0 & 0.346 \\
\hline 26 & DH 5-27 & $79.5 b$ & $80.7 \mathrm{~b}$ & $102.0 \mathrm{a}$ & 87.4 & 0.216 & 70 & DH 6-45 & $80.5 \mathrm{~b}$ & $82.5 b$ & $93.5 \mathrm{a}$ & 85.5 & 0.743 \\
\hline 27 & $\mathrm{D}$ & $78.0 \mathrm{~b}$ & $79.3 \mathrm{~b}$ & $101.0 \mathrm{a}$ & 86.2 & 257 & 71 & $6-46$ & $53.0 \mathrm{~b}$ & $54.0 \mathrm{~b}$ & $100.5 \mathrm{a}$ & 69.2 & 2.645 \\
\hline 28 & & $85.5 \mathrm{~b}$ & $86.3 \mathrm{~b}$ & $.0 \mathrm{a}$ & 9 & 26 & 72 & & $5 \mathrm{a}$ & $0 \mathrm{a}$ & $0 \mathrm{a}$ & .8 & 026 \\
\hline 29 & DH 6-4 & $73.5 \mathrm{~b}$ & $75.0 \mathrm{~b}$ & $91.0 \mathrm{a}$ & 79.8 & 0.284 & 73 & DH 6-48 & $73.0 \mathrm{~b}$ & $74.0 \mathrm{~b}$ & $103.5 \mathrm{a}$ & 83.5 & 0.999 \\
\hline 30 & DH 6-5 & $54.5 \mathrm{~b}$ & $56.5 \mathrm{~b}$ & $79.5 \mathrm{a}$ & 63.5 & 0.420 & 74 & DH 6-49 & $89.5 \mathrm{~b}$ & $90.7 \mathrm{~b}$ & $94.5 \mathrm{a}$ & 91.6 & 1.478 \\
\hline 31 & DH 6-6 & $90.5 \mathrm{~b}$ & $92.0 \mathrm{~b}$ & $115.5 \mathrm{a}$ & 99.3 & 0.443 & 75 & DH 6-50 & $67.0 \mathrm{~b}$ & $69.5 \mathrm{~b}$ & $91.5 \mathrm{a}$ & 76.0 & 0.349 \\
\hline 32 & DH 6-7 & $89.5 \mathrm{~b}$ & $90.3 \mathrm{~b}$ & $113.0 \mathrm{a}$ & 97.6 & 0.329 & 76 & DH 6-51 & $55.5 \mathrm{~b}$ & $57.3 \mathrm{~b}$ & $101.5 \mathrm{a}$ & 71.4 & 2.460 \\
\hline 33 & DH 6-8 & $78.0 \mathrm{~b}$ & $80.0 \mathrm{~b}$ & $96.5 \mathrm{a}$ & 84.8 & 0.212 & 77 & -52 & $78.5 \mathrm{~b}$ & $80.3 \mathrm{~b}$ & $112.5 \mathrm{a}$ & 90.4 & 1.298 \\
\hline 34 & DH 6-9 & $70.5 \mathrm{~b}$ & $74.0 \mathrm{~b}$ & $80.0 \mathrm{a}$ & 74.8 & 1.155 & 78 & DH 6-53 & $83.0 \mathrm{a}$ & $84.7 \mathrm{a}$ & $68.5 b$ & 78.7 & 3.390 \\
\hline 35 & DH 6-10 & $73.0 \mathrm{~b}$ & $76.5 b$ & $88.5 \mathrm{a}$ & 79.3 & 0.577 & 79 & DH 6-55 & $58.5 \mathrm{~b}$ & $61.0 \mathrm{~b}$ & $88.0 \mathrm{a}$ & 69.2 & 0.832 \\
\hline 36 & DH 6-11 & $82.0 \mathrm{~b}$ & $82.0 \mathrm{~b}$ & $105.0 \mathrm{a}$ & 89.7 & 0.322 & 80 & DH 6-56 & $58.5 \mathrm{~b}$ & $59.7 \mathrm{~b}$ & $89.5 \mathrm{a}$ & 69.2 & 1.039 \\
\hline 37 & DH 6-12 & $75.0 \mathrm{a}$ & $50.0 \mathrm{c}$ & $59.5 \mathrm{~b}$ & 61.5 & 2.353 & 81 & DH 6-59 & $80.0 \mathrm{~b}$ & $82.3 \mathrm{~b}$ & $91.0 \mathrm{a}$ & 84.4 & 0.953 \\
\hline 38 & DH 6-13 & $60.0 \mathrm{~b}$ & $61.0 \mathrm{~b}$ & $88.0 \mathrm{a}$ & 69.7 & 0.757 & 82 & DH 6-60 & $92.7 \mathrm{a}$ & $91.8 \mathrm{a}$ & $90.0 \mathrm{a}$ & 91.5 & 2.126 \\
\hline 39 & DH 6-14 & $61.5 \mathrm{~b}$ & $62.7 \mathrm{~b}$ & $76.5 \mathrm{a}$ & 66.9 & 0.510 & 83 & DH 6-61 & $92.0 \mathrm{~b}$ & $93.0 \mathrm{~b}$ & $105.5 \mathrm{a}$ & 96.8 & 0.647 \\
\hline 40 & DH 6-15 & $71.5 \mathrm{~b}$ & $74.0 \mathrm{~b}$ & $80.0 \mathrm{a}$ & 75.2 & 1.203 & 84 & DH 6-64 & $76.5 \mathrm{~b}$ & $77.7 \mathrm{~b}$ & $88.0 \mathrm{a}$ & 80.7 & 0.849 \\
\hline 41 & DH 6-16 & $83.5 \mathrm{~b}$ & $72.0 \mathrm{c}$ & $99.5 \mathrm{a}$ & 85.0 & 0.423 & 85 & DH 6-65 & $80.0 \mathrm{~b}$ & $81.3 \mathrm{~b}$ & $89.0 \mathrm{a}$ & 83.4 & 1.099 \\
\hline 42 & DH 6-17 & $64.0 \mathrm{c}$ & $87.5 \mathrm{~b}$ & $96.5 a$ & 82.7 & 0.682 & 86 & DH 6-66 & $59.0 \mathrm{~b}$ & $57.5 \mathrm{~b}$ & $87.5 \mathrm{a}$ & 68.0 & 0.928 \\
\hline 43 & DH 6-18 & $80.0 \mathrm{~b}$ & $74.0 \mathrm{c}$ & $99.0 \mathrm{a}$ & 84.3 & 0.305 & 87 & DH 6-67 & $85.0 \mathrm{~b}$ & $86.7 \mathrm{~b}$ & $102.0 \mathrm{a}$ & 91.2 & 0.340 \\
\hline 44 & DH 6-19 & $56.0 \mathrm{c}$ & $61.5 \mathrm{~b}$ & $66.5 a$ & 61.3 & 1.159 & \multicolumn{2}{|r|}{ Mean } & $74.3 \mathrm{C}$ & $75.5 \mathrm{~B}$ & $94.6 \mathrm{~A}$ & & \\
\hline
\end{tabular}


The biplot from Figure 3 based on the first two components, indicates that the year 2016 had the highest contribution to the interaction between genotypes and climatic conditions, while the years 20042005 had close effects, but considerably lower. Also, depending on the positions of the three years with respect to the first component axis it turns out that in 2016 were recorded the most favourable climatic conditions for the growth of wheat plants, while in 2004 the plants height presented the lowest values. According to the distance from the origin the lines: 'DH 6-24', 'G 603/86, ' $\mathrm{DH}$ 6-31', 'DH 6-39', 'DH 6-42', 'DH 6-23', presented the highest stability of plant height.

The length and position of the vectors for lines ' $\mathrm{DH} 5-22$ ' and ' $\mathrm{DH}$ 6-17' indicate a high instability of plant height, associated with significant variations (over $20 \mathrm{~cm}$ ) from year to year, with the highest values in 2016 and the lowest in 2004. The line 'DH 6-53' showed a high stability of plant height under the conditions from 2004-2005 and a significantly lower value in 2016. A special reaction is also observed in the case of the line 'DH 5-23' which registered a very small variation of plants height in 2004 and 2016, associated with significantly higher values compared to 2005 .

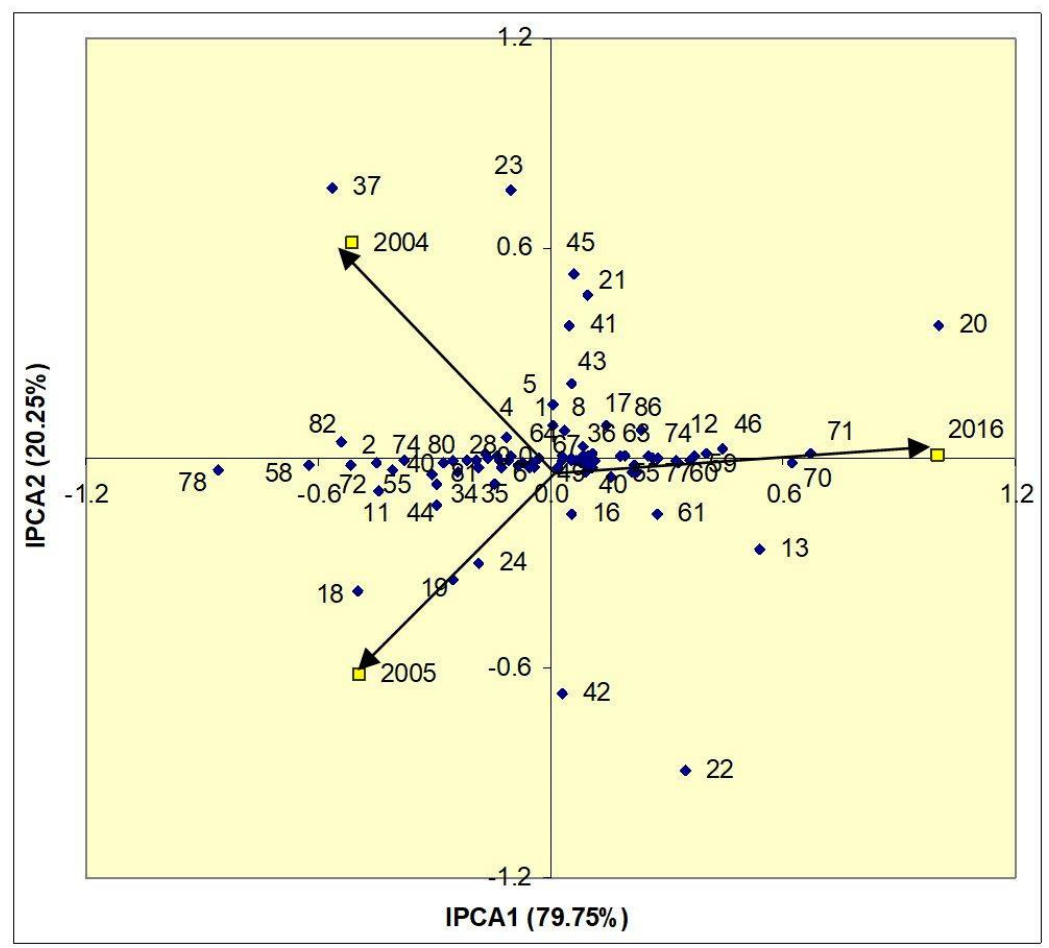

Figure 3. Biplot of interaction for principal component axis (IPCA1 and IPCA2) for plant height in 2004, 2005 and 2016

The line 'DH 6-12' has shown a specific adaptation to the conditions from 2004 when it recorded an increase of the plant height significantly higher by $15.5-25 \mathrm{~cm}$ compared to the other years. The line 'DH 5$20^{\prime}$ presented a very close adaptation to the conditions from 2016 using them very effectively, on the background of a plant height significantly superior to the values from 2004-2005. 
The combined analysis of the variance based on the AMMI 2 model for wheat genotypes over three years (Table 5) indicates that both genotype and climatic conditions, respectively their interaction had significant effects on ear emergence. The climatic conditions showed the highest influence $(62.22 \%)$ on the variability of this trait, while the genotype (19.94\%) and the genotype $\times$ year interaction $(17.84 \%)$ had similar influences. This model based on the first two principal components fully expresses the effect of genotype $\times$ year interaction on the emergence precocity, being appropriate for evaluating the stability of this trait in wheat lines.

Table 5. Combined analysis of variance according to the AMMI 2 model for ear emergence date

\begin{tabular}{|c|c|c|c|c|c|}
\hline Source of variation & SS & DF & MS & F & SS $\%^{1}$ \\
\hline Total & 30211 & 782 & & & \\
\hline Genotypes & 5980 & 86 & 69.53 & $163.86^{* *}$ & 19.94 \\
\hline Years & 18658 & 2 & 9329.00 & $21985^{* *}$ & 62.22 \\
\hline Genotypes x Years & 5351 & 172 & 31.11 & $73.32^{* *}$ & $17.84(100)$ \\
\hline IPCA 1 & 3812 & 87 & 43.82 & $104.87^{* *}$ & 71.23 \\
\hline IPCA 2 & 1540 & 85 & 18.11 & $43.35^{* *}$ & 28.77 \\
\hline IPCA residuals & 0 & 0 & & & \\
\hline Error & 221 & 522 & 0.42 & & \\
\hline
\end{tabular}

${ }^{1} \%$ of model sum of squares for genotype, year and genotype $\times$ year; ${ }^{* *}$ significant at $\mathrm{P} \leq 0.01$.

According to the data from Table 6 it is observed that generally the climatic conditions from 2016 have caused a significant precocity of ear emergence, while in 2005 there was a significant delay. Under the conditions from 2004, the ear emergence date registered amplitude of about 14 days. In this sense the earliest genotypes were: 'F 132', 'DH 5-21', 'DH 6-31', which emerged around May 11, while the line 'DH 6-45' which emerged around May 25 was the latest. The precocity of ear emergence in this year showed a symmetrical distribution of lines: $3.45 \%$ of the lines emerged in May 10 to 11; $41.38 \%$ emerged in May 11 to 16; 45.98\% emerged in May 16 to 21; 9.20\% of the lines emerged after May 21.

Under the conditions from 2005 there was a delay of ear emergence, amid amplitude of 10 days between the earliest lines ('F 132' and 'DH 5-1') which emerged on May 12 and the lines 'DH 5-4', 'DH 5-8', 'DH 5-10', 'DH 5-21', 'DH 6-20' which emerged on May 22, respectively. Thus, $29.89 \%$ of the lines emerged until May 16, while 59.77\% emerged in May 16 to 21, and 10.34\% emerged after May 21.

Amid a precocity compared to previous years, the ear emergence amplitude in 2016 was higher (17 days), ranging between April 28 for 'DH 6-33' and 'DH 6-46' lines, and May 15 for 'DH 5-4', 'DH 5-8' and 'DH 5.22' lines. Thus, $13.79 \%$ of the lines emerged before May 1; $3.45 \%$ in May 1; $37.93 \%$ in May 2 to 5; $16,09 \%$ in May 6 to $11 ; 28.74 \%$ after May 11.

Compared to the parental forms, during the study $62.5 \%$ of the ' $\mathrm{DH} 5$ ' lines presented a later ear emergence than the parents mean, and four lines were later than both parents, without being registered earlier lines than 'F.132'. In the case of the ' $\mathrm{DH} 6$ ' series, $49.18 \%$ of the lines showed a later ear emergence than the parents mean, in this respect the lines ' $\mathrm{DH}$ 6-3' and 'DH 6-20' were later than paternal parent 'G 603/86', while only the line 'DH 6-31' was earlier than maternal parent 'F.132'.

Regarding the annual values of this trait, it is found that about $11.5 \%$ of the lines did not show significant variations of ear emergence in 2004-2005, while about $90 \%$ of the lines have shown significant differences of this trait from one year to another.

According to values of ASV parameter (Table 6) it is noted that the highest stability of ear emergence was presented by the lines: 'DH 6-8', 'DH 6-67', 'DH 6-30', 'DH 6-19', 'DH 5-13', 'DH 6-28', 'DH 6-4', 'DH 6-13'. The high stability of the lines: 'DH 6-30', 'DH 6-13', 'DH 6-28', 'DH 6-67', 'DH 6-19', has been associated with a good precocity, an ear emergence around May 9-10, respectively. 
Table 6. Ear emergence date for wheat genotypes in 2004, 2005 and 2016

\begin{tabular}{|c|c|c|c|c|c|c|c|c|c|c|c|c|c|}
\hline No. & Genotype & $2004^{*}$ & $2005^{*}$ & $2016^{*}$ & Mean* & ASV & No. & Genotype & $2004^{*}$ & $2005^{*}$ & $2016^{*}$ & Mean* & ASV \\
\hline P1 & G 603/86 & $16.7 \mathrm{~b}$ & $20.3 a$ & $12.0 \mathrm{c}$ & 16.3 & 1.007 & 45 & DH 6-20 & $20.3 a$ & $21.0 \mathrm{a}$ & $12.3 \mathrm{~b}$ & 17.9 & 0.431 \\
\hline P2 & F 132 & $9.7 \mathrm{~b}$ & $11.0 \mathrm{a}$ & $2.0 \mathrm{c}$ & 7.6 & 0.481 & 46 & DH 6-21 & $18.7 \mathrm{a}$ & $11.3 \mathrm{c}$ & $12.7 \mathrm{~b}$ & 14.2 & .529 \\
\hline 3 & DH 5-1 & $17.3 \mathrm{a}$ & $11.0 \mathrm{~b}$ & $0.7 \mathrm{c}$ & 9.7 & 1.255 & 47 & DH 6-22 & $12.3 \mathrm{~b}$ & $17.7 \mathrm{a}$ & $9.3 \mathrm{c}$ & 13.1 & 1.181 \\
\hline 4 & DH 5-2 & $20.7 \mathrm{a}$ & $16.0 \mathrm{~b}$ & $6.0 \mathrm{c}$ & 14.2 & 0.814 & 48 & DH 6-23 & $11.7 \mathrm{~b}$ & $19.0 \mathrm{a}$ & $11.0 \mathrm{~b}$ & 13.9 & 1.717 \\
\hline 5 & DH 5-3 & $17.3 \mathrm{a}$ & $15.3 \mathrm{~b}$ & $3.7 \mathrm{c}$ & 12.1 & 0.725 & 49 & DH 6-24 & $17.3 \mathrm{a}$ & $12.0 \mathrm{~b}$ & $-2.0 c$ & 9.1 & 1.727 \\
\hline 6 & DH 5-4 & $18.7 \mathrm{~b}$ & $21.0 \mathrm{a}$ & $14.0 \mathrm{c}$ & 17.9 & 1.058 & 50 & DH 6-25 & $21.3 \mathrm{a}$ & $17.7 \mathrm{~b}$ & $7.0 \mathrm{c}$ & 15.3 & 0.807 \\
\hline 7 & DH 5-5 & $11.3 \mathrm{~b}$ & $14.7 \mathrm{a}$ & $3.7 \mathrm{c}$ & 9.9 & 0.364 & 51 & DH 6-26 & $15.3 \mathrm{~b}$ & $19.7 \mathrm{a}$ & $12.3 \mathrm{c}$ & 15.8 & 1.207 \\
\hline 8 & DH 5-6 & $18.7 \mathrm{a}$ & $12.0 \mathrm{~b}$ & $-1.7 \mathrm{c}$ & 9.7 & 1.805 & 52 & DH 6-27 & $13.0 \mathrm{~b}$ & $15.7 \mathrm{a}$ & $2.7 \mathrm{c}$ & 10.4 & 0.321 \\
\hline 9 & DH 5-7 & $16.3 \mathrm{a}$ & $16.0 \mathrm{a}$ & $2.7 \mathrm{~b}$ & 11.7 & 0.775 & 53 & DH 6-28 & $10.5 \mathrm{~b}$ & $13.0 \mathrm{a}$ & $1.5 \mathrm{c}$ & 8.3 & 0.210 \\
\hline 10 & DH 5-8 & $17.7 \mathrm{~b}$ & $21.0 \mathrm{a}$ & $14.0 \mathrm{c}$ & 17.6 & 1.223 & 54 & DH 6-29 & $20.0 \mathrm{a}$ & $19.3 \mathrm{a}$ & $9.3 \mathrm{~b}$ & 16.2 & 0.284 \\
\hline 11 & DH 5-9 & $15.3 b$ & $19.7 \mathrm{a}$ & $11.3 \mathrm{c}$ & 15.4 & 1.106 & 55 & DH 6-30 & $11.3 \mathrm{a}$ & $11.7 \mathrm{a}$ & $1.3 \mathrm{~b}$ & 8.1 & 0.080 \\
\hline 12 & DH 5-10 & $16.3 \mathrm{~b}$ & $21.0 \mathrm{a}$ & $12.7 \mathrm{c}$ & 16.7 & 1.094 & 56 & DH 6-31 & $9.7 \mathrm{~b}$ & $13.7 \mathrm{a}$ & $-2.0 c$ & 7.1 & 0.621 \\
\hline 13 & DH 5-11 & $15.7 \mathrm{~b}$ & $20.3 a$ & $11.7 \mathrm{c}$ & 15.9 & 1.084 & 57 & DH 6-32 & $17.0 \mathrm{a}$ & $13.0 \mathrm{~b}$ & $9.7 \mathrm{c}$ & 13.2 & 0.908 \\
\hline 14 & DH 5-12 & $16.3 \mathrm{~b}$ & $20.7 \mathrm{a}$ & $12.0 \mathrm{c}$ & 16.3 & 1.007 & 58 & DH 6-33 & $16.3 \mathrm{~b}$ & $18.7 \mathrm{a}$ & $-3.0 c$ & 10.7 & .079 \\
\hline 15 & DH 5-13 & $13.7 \mathrm{~b}$ & $16.0 \mathrm{a}$ & $4.0 \mathrm{c}$ & 11.2 & 0.186 & 59 & DH 6-34 & $13.0 \mathrm{a}$ & $11.7 \mathrm{~b}$ & $1.0 \mathrm{c}$ & 8.6 & 0.449 \\
\hline 16 & $\mathrm{DH}$ & $12.7 \mathrm{~b}$ & $17.3 \mathrm{a}$ & $3.3 \mathrm{c}$ & 11.1 & 0.390 & 60 & -35 & $14.7 \mathrm{a}$ & $15.7 \mathrm{a}$ & $2.7 \mathrm{~b}$ & 11.0 & 0.478 \\
\hline 17 & DH 5-17 & $14.3 \mathrm{~b}$ & $18.0 \mathrm{a}$ & $3.7 \mathrm{c}$ & 12.0 & 0.480 & 61 & DH 6-36 & $19.3 \mathrm{a}$ & $15.3 \mathrm{~b}$ & $4.3 c$ & 13.0 & 0.985 \\
\hline 18 & DH 5-18 & $10.7 \mathrm{~b}$ & $14.3 \mathrm{a}$ & $-0.3 c$ & 8.2 & 0.592 & 62 & DH 6-37 & $20.0 \mathrm{a}$ & $16.3 \mathrm{~b}$ & $-2.0 c$ & 11.4 & 2.360 \\
\hline 19 & DH 5-19 & $13.7 \mathrm{a}$ & $11.3 \mathrm{~b}$ & $0.0 \mathrm{c}$ & 8.3 & 0.629 & 63 & -38 & $17.3 \mathrm{a}$ & $12.3 \mathrm{~b}$ & $-1.7 \mathrm{c}$ & 9.3 & 1.738 \\
\hline 20 & -20 & $19.0 \mathrm{a}$ & $14.0 \mathrm{~b}$ & $12.3 \mathrm{c}$ & 15.1 & 1.225 & 64 & -39 & $14.3 \mathrm{~b}$ & $15.7 \mathrm{a}$ & $2.3 \mathrm{c}$ & 10.8 & 0.440 \\
\hline 21 & -21 & $9.7 \mathrm{c}$ & $21.0 \mathrm{a}$ & $13.7 \mathrm{~b}$ & 14.8 & 2.519 & 65 & 40 & $13.7 \mathrm{~b}$ & $16.0 \mathrm{a}$ & $0.0 \mathrm{c}$ & 9.9 & 0.867 \\
\hline 22 & DH 5.22 & $15.3 \mathrm{a}$ & $11.3 \mathrm{c}$ & $14.0 \mathrm{~b}$ & 13.6 & 2.127 & 66 & DH 6-41 & $11.3 \mathrm{~b}$ & $15.3 \mathrm{a}$ & $-2.3 c$ & 8.1 & 1.098 \\
\hline 23 & DH 5-23 & $13.7 \mathrm{~b}$ & $17.0 \mathrm{a}$ & $5.3 c$ & 12.0 & 0.378 & 67 & DH 6-42 & $16.0 \mathrm{a}$ & $15.7 \mathrm{a}$ & $0.7 \mathrm{~b}$ & 10.8 & 1.167 \\
\hline 24 & DH 5-25 & $12.3 \mathrm{~b}$ & $15.0 \mathrm{a}$ & $4.0 \mathrm{c}$ & 10.4 & 0.275 & 68 & DH 6-43 & $14.3 \mathrm{~b}$ & $18.3 \mathrm{a}$ & $1.0 \mathrm{c}$ & 11.2 & 0.999 \\
\hline 25 & DH 5-26 & $16.3 \mathrm{~b}$ & $18.7 \mathrm{a}$ & $8.7 \mathrm{c}$ & 14.6 & 0.463 & 69 & DH 6-44 & $17.3 \mathrm{a}$ & $12.0 \mathrm{~b}$ & $1.0 \mathrm{c}$ & 0.1 & 1.163 \\
\hline 26 & DH 5-27 & $14.7 \mathrm{~b}$ & $17.3 \mathrm{a}$ & $3 c$ & 1 & 49 & 70 & $6-45$ & $23.3 a$ & $14.0 \mathrm{~b}$ & $1.3 \mathrm{c}$ & 12.9 & 2.150 \\
\hline 27 & DH 6-1 & $15.3 \mathrm{~b}$ & $16.7 \mathrm{a}$ & $7 \mathrm{c}$ & 3.2 & 99 & 71 & & $7 \mathrm{~b}$ & $14.7 \mathrm{a}$ & $-2.7 \mathrm{c}$ & 7.9 & 011 \\
\hline 28 & DH 6-3 & $21.0 \mathrm{a}$ & $19.3 \mathrm{~b}$ & $11.0 \mathrm{c}$ & 17.1 & 0.269 & 72 & DH 6-47 & $18.3 \mathrm{a}$ & $15.7 \mathrm{~b}$ & $2.3 c$ & 12.1 & 1.095 \\
\hline 29 & DH 6-4 & $13.7 \mathrm{~b}$ & $16.3 a$ & $3.7 \mathrm{c}$ & 11.2 & 0.218 & 73 & DH 6-48 & $15.0 \mathrm{~b}$ & $16.3 a$ & $12.0 \mathrm{c}$ & 14.4 & 1.375 \\
\hline 30 & DH 6-5 & $14.7 \mathrm{~b}$ & $16.0 \mathrm{a}$ & $3.3 c$ & 11.3 & 0.274 & 74 & DH 6-49 & $20.3 a$ & $18.7 \mathrm{~b}$ & $-1.3 c$ & 12.6 & 2.366 \\
\hline 31 & DH 6-6 & $15.7 \mathrm{~b}$ & $17.7 \mathrm{a}$ & $10.3 \mathrm{c}$ & 14.6 & 0.955 & 75 & $6-50$ & $18.7 \mathrm{a}$ & $14.7 \mathrm{~b}$ & $-1.7 \mathrm{c}$ & 10.6 & 868 \\
\hline 32 & $\mathrm{DH}$ & $14.3 \mathrm{~b}$ & $17.3 \mathrm{a}$ & $9.7 \mathrm{c}$ & 3.8 & 0.936 & 76 & -51 & $12.3 \mathrm{~b}$ & $14.3 \mathrm{a}$ & $1.7 \mathrm{c}$ & 9.4 & 0.321 \\
\hline 33 & DH 6-8 & $15.7 \mathrm{a}$ & $16.0 \mathrm{a}$ & $5.7 \mathrm{~b}$ & 12.4 & 0.020 & 77 & DH 6-52 & $11.3 \mathrm{~b}$ & $15.0 \mathrm{a}$ & $11.0 \mathrm{~b}$ & 12.4 & 1.865 \\
\hline 34 & DH 6-9 & $15.3 \mathrm{~b}$ & $18.3 \mathrm{a}$ & $11.0 \mathrm{c}$ & 14.9 & 1.038 & 78 & DH 6-53 & $13.0 \mathrm{~b}$ & $19.7 \mathrm{a}$ & $4.0 \mathrm{~b}$ & 12.2 & 0.586 \\
\hline 35 & DH 6-10 & $16.0 \mathrm{a}$ & $14.3 \mathrm{~b}$ & $3.0 \mathrm{c}$ & 11.1 & 0.541 & 79 & DH 6-55 & $11.3 \mathrm{~b}$ & $16.0 \mathrm{a}$ & $-2.0 c$ & 8.4 & 1.046 \\
\hline 36 & DH 6-11 & $17.7 \mathrm{~b}$ & $19.7 \mathrm{a}$ & $12.3 \mathrm{c}$ & 16.6 & 0.977 & 80 & DH 6-56 & $14.7 \mathrm{~b}$ & $16.0 \mathrm{a}$ & $0.0 \mathrm{c}$ & 10.2 & 0.998 \\
\hline 37 & DH 6-12 & $16.7 \mathrm{~b}$ & $18.0 \mathrm{a}$ & $9.7 \mathrm{c}$ & 14.8 & 0.585 & 81 & DH & $12.3 \mathrm{~b}$ & $15.0 \mathrm{a}$ & $2.0 \mathrm{c}$ & 9.8 & 0.286 \\
\hline 38 & DH 6-13 & $11.3 \mathrm{~b}$ & $12.7 \mathrm{a}$ & $0.7 \mathrm{c}$ & 8.2 & 0.232 & 82 & DH 6-60 & $13.3 \mathrm{~b}$ & $15.7 \mathrm{a}$ & $3.0 \mathrm{c}$ & 10.7 & 0.230 \\
\hline 39 & DH 6-14 & $14.7 \mathrm{~b}$ & $16.0 \mathrm{a}$ & $8.7 \mathrm{c}$ & 13.1 & 0.793 & 83 & DH 6-61 & $16.7 \mathrm{~b}$ & $20.0 \mathrm{a}$ & $11.7 \mathrm{c}$ & 16.1 & 0.921 \\
\hline 40 & DH 6-15 & $18.3 \mathrm{a}$ & $17.3 \mathrm{a}$ & $7.7 \mathrm{~b}$ & 14.4 & 0.232 & 84 & DH 6-64 & $17.3 \mathrm{a}$ & $16.0 \mathrm{~b}$ & $4.0 \mathrm{c}$ & 12.4 & 0.638 \\
\hline 41 & DH 6-16 & $17.3 \mathrm{a}$ & $18.0 \mathrm{a}$ & $10.3 \mathrm{~b}$ & 15.2 & 0.641 & 85 & DH 6-65 & $16.0 \mathrm{~b}$ & $19.3 \mathrm{a}$ & $13.0 \mathrm{c}$ & 16.1 & 1.265 \\
\hline 42 & DH 6-17 & $17.7 \mathrm{a}$ & $15.0 \mathrm{~b}$ & $13.0 \mathrm{c}$ & 15.2 & 1.389 & 86 & DH 6-66 & $14.3 \mathrm{~b}$ & $16.0 \mathrm{a}$ & $3.3 \mathrm{c}$ & 11.2 & 0.375 \\
\hline 43 & DH 6-18 & $18.3 \mathrm{a}$ & $11.7 \mathrm{~b}$ & $12.3 \mathrm{~b}$ & 14.1 & 1.529 & 87 & DH 6-67 & $12.7 \mathrm{a}$ & $13.3 \mathrm{a}$ & $2.3 \mathrm{~b}$ & 9.4 & 0.039 \\
\hline 44 & DH 6-19 & $12.7 \mathrm{~b}$ & $14.3 \mathrm{a}$ & $2.7 \mathrm{c}$ & 9.9 & 0.158 & & Mean & $15.4 \mathrm{~B}$ & $16.1 \mathrm{~A}$ & $5.5 \mathrm{C}$ & & \\
\hline
\end{tabular}


Based on the biplot from Figure 4 and considering that the IPCA1 axis expresses about $71.23 \%$ of the genotype $\times$ year interaction, it can be seen that the lines showed a considerable delay of the ear emergence in 2004-2005 compared with 2016. Also, according to the coordinates of each year it turns out that the conditions from 2016 showed a higher contribution to the genotype $\times$ year interaction, while the conditions from 2005 had a smaller effect on the respective interaction.

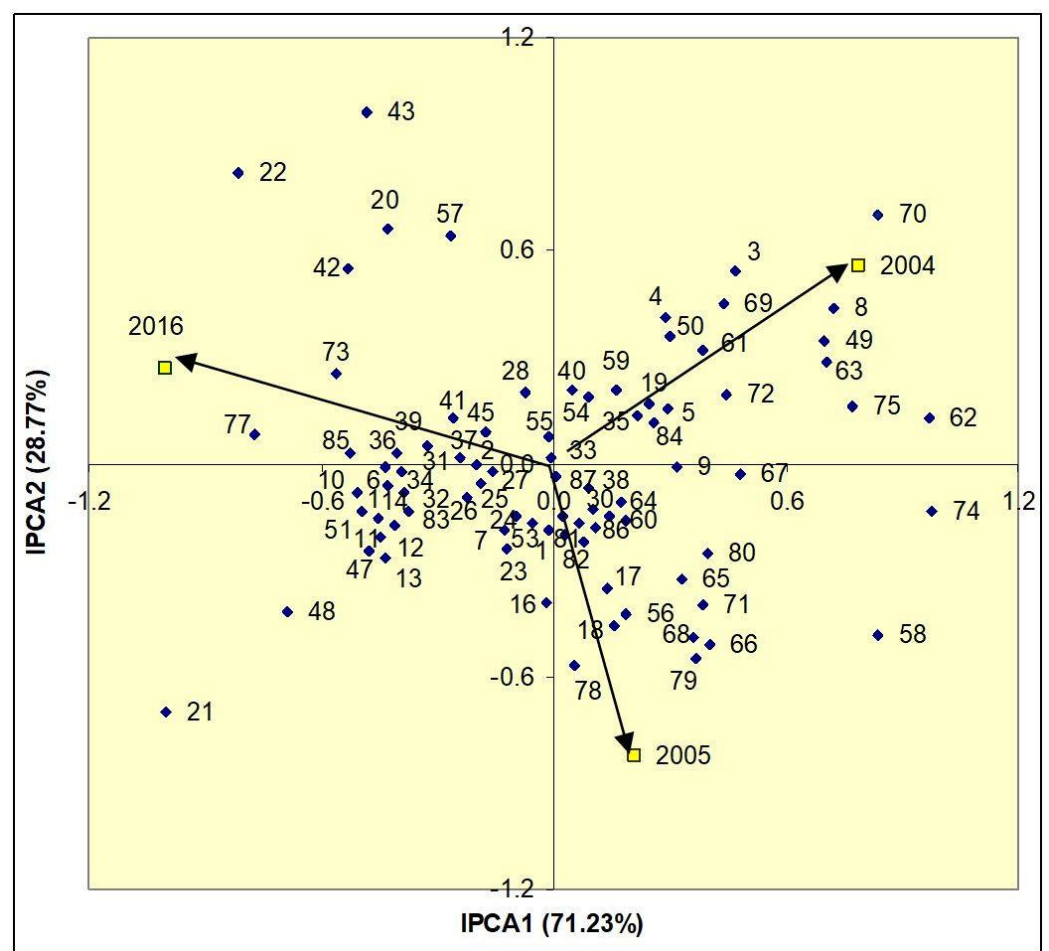

Figure 4. Biplot of interaction for principal component axis (IPCA1 and IPCA2) for ear emergence of wheat genotypes during 2004-2005 and 2016

The close position to the origin in case of lines: 'DH 6-21', 'DH 6-6', 'DH 6-4', 'DH 5-6', 'DH 6-38', indicates high stability of ear emergence (Figure 4). Considering the distance from the origin, it is observed that the lines: 'DH 6-18', 'DH 5-22', 'DH 5-20', 'DH 6-17', 'DH 6-32', shows a low stability associated with a late ear emergence. For lines 'DH 6-37', 'DH 6-49', 'DH 6-33', 'DH 6-50' and 'DH 6-45', the high instability is associated with an earlier ear emergence in 2016 compared to 2004-2005. The line 'DH 5-21', presented a high interaction with the climatic conditions during the study expressing a particular reaction, namely a considerably earlier ear emergence in 2004 compared to 2005 and 2016.

\section{Discussion}

The studied genotypes are suitable for this work, considering that $\mathrm{DH}$ lines obtained via maize hybridization are the most useful for research studies and for the breeding of new wheat cultivars. The probability of segregation modification and loss of desirable genotypes in these populations is significantly lower than in anther-derived populations (Adamski et al., 2014). DH populations were efficiently used in other studies (Zhang et al., 2009; Gegas et al., 2010; Heidari et al., 2011; Ganev aet al., 2014; Zhang et al., 2014; Griffith et al., 2015; Guo et al., 2015; Zhang et al., 2016; Liu et al., 2018) for the analysis of the relationships among different yield components in wheat. 
The environmental conditions of the three years had an important contribution on the genotype $x$ year interaction, which showed also a higher influence on TKW. The variability of plant height and ear emergence data was also affected to a similar extent by this interaction. Significant effect of GE interaction on TKW has been previously reported by other studies (Gómez-Becerra et al., 2010; Tayyar, 2010; Sharma et al., 2013; Khazratkulova et al., 2015; Krishnappa et al., 2019). The high contribution of the genotype to the variation of TKW and plant height indicates that for the studied DH lines these two traits are most stable compared with ear emergence. Van Frank et al. (2020), found a close stability of breeding populations and commercial varieties for plant height and TKW. Barbu et al. (2018) reported that the reduced plant height and its stability in wheat were not correlated with the genetic background of this trait.

Compared to the parental forms, during the study $20.83 \%$ of the DH 5 lines presented an average value of TKW higher than the parents mean, $4.16 \%$ were lower than both parents, without being registered lines with values of this trait higher than the superior parent ('G 603/86'). In the case of the 'DH 6 ' series, $34.34 \%$ of the lines achieved a TKW higher than the parents mean, in this respect the line 'DH 6-7' which exceeded the best parent, was highlighted. Also, $4.92 \%$ of ' $\mathrm{DH} 6$ ' lines were lower than both parents. Significant increases of TKW compared to parents mean were also reported by other studies: $15.92 \%$ by Bao et al. (2009); 5.1\% by Simmonds et al. (2014). Considering that previously studies (Wang et al., 2012; Zhang et al., 2012) reported in wheat a linear correlation between TKW and favourable alleles, the DH lines with high values of TGW can be used as parents for crosses to ensure pyramiding the maximum number of favourable alleles in a valuable genetic background.

The grain yield is strongly influenced by the plant height, which can be used as a selection criterion for improving grain yield in wheat (Mohammadi et al., 2012). In comparison with the parental forms, it is found that most of the lines (80.84\%) of the 'DH 5 ' series recorded a plant height below the parents mean, or even lower than both parents in the case of $29.16 \%$ of the lines. Only the line 'DH 5-10' showed a higher value to both parents. In the case of the 'DH 6 ' series, $29.5 \%$ of the lines achieved a lower plant height than both parents, $70.5 \%$ had an intermediate value to parental forms while four lines were superior to both parents. A large variation of plant height in $\mathrm{DH}$ populations compared to parents mean was also reported by other studies (Inagaki et al., 1998; Heidari et al., 2012). Likewise, El-Hennawy et al. (2011) observed in five DH populations, several transgressive segregants for plant height in both directions. As well, Wu et al. (2010) reported that the plant height of wheat DH lines showed continuous variation and transgressive segregation in different growth stages and environments. Wheat $\mathrm{DH}$ populations are an effective material to be used for studying the molecular genetic basis of plant height (Li et al., 2010; Wu et al., 2010; Zhang et al., 2011; Heidari et al., 2012).

As against the parental forms, during the study $62.5 \%$ of the ' $\mathrm{DH} 5$ ' lines presented a later ear emergence than the parents mean and four lines were later than both parents, without being registered earlier lines than 'F.132'. In the case of the ' $\mathrm{DH} 6$ ' series, $49.18 \%$ of the lines showed a later ear emergence than the parents mean, in this respect the lines 'DH 6-3' and 'DH 6-20' were later than paternal parent ' $\mathrm{G}$ 603/86', while only the line 'DH 6-31' was earlier than maternal parent 'F.132'. These results are in agreement with those of Kuchel et al. (2006) who reported that more than 50\% of the individuals from a wheat DH population emerge later than both parents under an average daily temperature during the duration of heading of $12.7^{\circ} \mathrm{C}$, while under an average daily temperature of an average daily temperature of $16.3^{\circ} \mathrm{C}$ more than $70 \%$ of the DH population were later than the parents. In another study Lantos et al. (2019) reported that the DH lines showed close or a little later ear emergence in comparison with their parent. Also, an important variation of heading date up to 13 days, in DH lines compared with the parents mean was found by Heidari et al. (2012). A large genetic variability for total time to anthesis and duration of pre-anthesis phases in DH populations was observed by Borràs-Gelonch et al. (2012), Coleman et al. (2001) and Rebetzke et al. (2008), These transgressive segregations, indicates the existence of multiple, independent alleles at different loci between the parents of the $\mathrm{DH}$ populations (Borràs-Gelonch et al., 2012). 
Taking into account that grain yield can be increased by growing varieties which heading time allows to avoid different stresses during grain-filling phase (Kamran et al., 2014), and considering that several QTLs for grain shape, size and yield were detected, near the loci for photoperiod sensitivity (Maphosa et al., 2014), some of the studied DH lines can be used for simultaneous improvements of different target traits.

\section{Conclusions}

Based on the performed results and analyses, were highlighted the lines: 'DH 6-7' (64.53 g), 'DH 5-11' (61.72 g), 'DH 6-6' (61.02 g), 'DH 6-29' (57.48 g), 'DH 6-59' (56.49 g), 'DH 6-21' (54.78 g), 'DH 6-42' $(54.37 \mathrm{~g})$, which show high and stable values of TKW, associated with a plants height of approximately 85 $100 \mathrm{~cm}$ and an ear emergence from May 11 to 17, under some climatic conditions similar to the period of study. The line 'DH 5-10' showed a specific adaptation to less favourable wheat conditions represented by a lower level of precipitation during the spring growth period in 2004, achieving a significantly higher TKW by 11-16 g compared to the values of the others years. The lines 'DH 6-31', 'DH 6-67' and 'DH 6-56', have shown a high potential to effectively exploit the favourable conditions in spring, achieving high levels of TKW amid an earlier ear emergence between April 29 and May 4. The above-mentioned doubled haploids lines can be considered as promising genotypes for using in wheat breeding programs in order to improve yield performances under temperate continental climate conditions.

\section{Authors' Contributions}

Conceptualization: SC, AG and AC; Methodology: AG; Data analysis and interpretation: SC and AC; Writing- original draft: SC, AG and AC; Writing-review and editing: SC, AG and AC. All authors read and approved the final manuscript.

\section{Acknowledgements}

This research was supported by the project financed by the Ministry of Research and Innovation (MCI) through Program 1 - Development of the national research and development system, Subprogram 1.2 - Institutional performance, Institutional development projects - Projects to fund excellence in RDI, code $35 \mathrm{PFE} / 2018$.

\section{Conflict of Interests}

The authors declare that there are no conflicts of interest related to this article.

\section{References}

Adamski T, Krystkowiak K, Kuczyńska A, Mikołajczak K, Ogrodowicz P, Ponitka A, ... Ślusarkiewicz-Jarzina A (2014). Segregation distortion in homozygous lines obtained via anther culture and maize doubled haploid methods in comparison to single seed descent in wheat (Triticum aestivum L.). Electronic Journal of Biotechnology 17:613. https://doi.org/10.1016/j.ejbt.2013.12.002

Bao Y-G, Wang S, Wang X-Q, Wang Y-H, Li X-F, Wang L, Wang H-G (2009). Heterosis and combining ability for major yield traits of a new wheat germplasm Shannong 0095 derived from Thinopyrum intermedium. Agricultural Sciences in China 8(6):753-760. https://doi.org/10.1016/S1671-2927(08)60275-8 
Barbu S, Giura A., Cristina D, Cornea C (2018). The influence of climatic variations on the stability of wheat plant height. Agriculture for Life, Life for Agriculture Conference Proceedings 1(1):508-514. https://doi.org/10.2478/alife-2018-0080

Borràs-Gelonch G, RebetzkeGJ, Richards RA, Romagosa I (2012). Genetic control of duration of pre-anthesis phases in wheat (Triticum aestivum L.) and relationships to leaf appearance, tillering, and dry matter accumulation. Journal of Experimental Botany 63(1):69-89. https://doi.org/10.1093/jxb/err230

Börner A, Schumann E, Fürste A, Coster H, Leithold B, Roder MS, Weber WE (2002). Mapping of quantitative trait locus determining agronomic important characters in hexaploid wheat (Triticum aestivum L.). Theoretical and Applied Genetics 105(6-7):921-936. https://doi.org/10.1007/s00122-002-994-1

Chojecki AJS, Gale MD, Bayliss MW (1983). Reciprocal monosomic analysis of grain size in wheat. In: Sakamoto S (Ed). Proc. $6^{\text {th }}$ Int. Wheat Genetics Symp. Kyoto, Japan pp 1061-1071.

Cheng X, Chai L, Chen Z, Xu L, Zhai H., Zhao A, ... Ni Z (2015). Identification and characterization of a high kernel weight mutant induced by gamma radiation in wheat (Triticum aestivum L.) BMC Genetics 16:127. https://doi.org/10.1186/s12863-015-0285-X

Ciulca S (2006). Metodologii de experimentare în agricultura şi biologie [Experimental methodologies in agriculture and biology]. Agroprint, Timisoara, Romania.

Coleman RK, Gill GS, Rebetzke GJ (2001). Identification of quantitative trait loci for traits conferring weed competitiveness in wheat (Triticum aestivum L.). Australian Journal of Agricultural Research 52:1235-1246.

Cui F, Ding A, Li X, Feng D, Wang X, Wang L, Gao J, Wang H (2011). Wheat kernel dimensions: how do they contribute to kernel weight at an individual OTL level?. Journal of Genetics 90:409-425. https://doi.org/10.1007/s12041-011-0103-9

Dobre PS, Giura A (2016). Protein content, thousand kernel weight (TKW) and volumetric mass (VM) in a set of wheat mutated and mutated/recombinant DH lines. Agrolife Scientific Journal 5(1):59- 62.

Dunwell JM (2010). Haploids in flowering plants: origins and exploitation. Plant Biotechnology Journal 8:377-424. https://doi.org/10.1111/j.1467-7652.2009.00498.x

El-Hennawy MA, Abdalla AF, ShafeyI SA, Al-Ashka M (2011). Production of doubled haploid wheat lines (Triticum aestivum L.) using anther culture technique. Annals of Agricultural Sciences 56(2):63-72. https://doi.org/10.1016/j.aoas.2011.05.008

Frank van G, Rivière P, Pin S, Baltassat R, Berthellot J-F, Caizergues F, ... Goldringer I (2020). Genetic diversity and stability of performance of wheat population varieties developed by participatory breeding. Sustainability 12:384. https://doi.org/10.3390/su12010384

Ganeva G, Landjeva S, Belchev I, Koleva L (2014). Characterization of two wheat doubled haploid populations for resistance to common bunt and its association with agronomic traits. Cereal Research Communications 42(3):484-494. https://doi.org/10.1556/CRC.42.2014.3.11

Gegas VC, Nazari A, Griffiths S, Simmonds, Fish L, Orford S, ... Snape JW (2010). A genetic framework for grain size and shape variation in wheat. Plant Cell 22:1046-1056. https://doi.org/10.1105/tpc.110.074153

Giura A (2010). Development of new genetic stocks for alien introgression in wheat. Journal of Horticulture, Forestry and Biotechnology 14:325-330.

Giura A, Săulescu NN (1996). Chromosomal location of genes controlling grain size in a large grained selection of wheat (Triticum aestivum L.). Euphytica 89:77-80. https://doi.org/10.1007/BF00015722

Gómez-Becerra HF, Abugalieva A, Morgounov A, Abdullaev K, Bekenova L, Yessimbekova M, ... Cakmak I (2010). Phenotypic correlations, $\mathrm{G} \times \mathrm{E}$ interactions and broad sense heritability analysis of grain and flour quality characteristics in high latitude spring bread wheats from Kazakhstan and Siberia. Euphytica 171:23-38. https://doi.org/10.1007/s10681-009-9984-6

Griffiths S, Wingen L, Pietragalla J, Garcia G, Hasan A, Miralles D, ... Reynolds M (2015). Genetic dissection of grain size and grain number trade- offs in CIMMYT wheat germplasm. PLoS One 10(3):e0118847. https://doi.org/10.1371/journal.pone.0118847

Guo J, Hao CY, Zhang Y, Zhang BQ, Cheng XM, Qin L, ... Cheng S (2015). Association and validation of yield-favored alleles in Chinese cultivars of common wheat (Triticum aestivum L.). PLoS One 10(6):e0130029. https://doi.org/10.1371/journal.pone.0130029

Halloran GM (1976). Genetic analysis of hexaploid wheat, Triticum aestivum using intervarietal chromosome substitution lines- protein content and grain weight. Euphytica 25:65-71. https://doi.org/10.1007/BF00041529 
Heidari B, Sayed-Tabatabaei BE, Saeidi G, Kearsey M, Suenaga K (2011). Mapping QTL for grain yield, yield components, and spike features in a doubled haploid population of bread wheat. Genome 54:517-527. https://doi.org/10.1139/g11-017

Heidari B, Saeidi G, Sayed Tabatabaei BE, Suenaga K (2012). QTLs involved in plant height, peduncle length and heading date of wheat (Triticum aestivum L.). Journal of Agricultural Science and Technology 14:1093-1104

Inagaki MN, Varughese G,Rajaram S, Kazi AM (1998). Comparison of bread wheat lines selected by doubled haploid, single-seed descent and pedigree selection methods. Theoretical and Applied Genetics 97(4):550-556. https://doi.org/10.1007/s001220050930

Kamran A., Iqbal M, Spaner D (2014). Flowering time in wheat (Triticum aestivum L.): a key factor for global adaptability. Euphytica197:1-26. https://doi.org/10.1007/s10681-014-1075-7

KhazratkulovaS, Sharma RC, Amanov A, Ziyaddulaev Z, Amanov O, Alikulov S, ... Muzafarova D (2015). Genotype $\times$ environment interaction and stability of grain yield and selected quality traits in winter wheat in Central Asia. Turkish Journal of Agriculture and Forestry 39:920-929. https://doi.org/10.3906/tar-1501-24

Krishnappa G, Ahlawat AK, Shukla RB, Singh SK, Singh SK, Singh AM, Singh GP (2019). Multi-environment analysis of grain quality traits in recombinant inbred lines of a biparental cross in bread wheat (Triticum aestivum L.). Cereal Research Communications 47:334-344. https://doi.org/10.1556/0806.47.2019.02

Kuchel H, Hollamby G, Langridge P, Williams K, Jefferies SP (2006). Identification of genetic loci associated with earemergence in bread wheat. Theoretical and Applied Genetics 113:1103-1112. https://doi.org/10.1007/s00122-006-0370-7

Lantos C, Purgel S, Ács K, Langó B, Bóna L, Boda K, Békés F, Pauk J (2019). Utilization of in vitro anther culture in spelt wheat breeding. Plants 8(10):436. https://doi.org/10.3390/plants8100436

Law CN (1967). The location of genetic factors controlling a number of quantitative characters in wheat. Genetics 56:445-461.

Li Z-K, Xie Q-G, Zhu Z-L, Liu J-L, Han S-X, Tian B, ... Tian C (2010). Analysis of plant height heterosis based on QTL mapping in wheat. Acta Agronomica Sinica 36(5):771-778. https://doi.org/10.1016/S18752780(09)60049-3

Li X, Lou X, Gao Z, Liu D, Sun J, Yang W, ... Zhang A (2019). Characterization of four favorable alleles conferring high thousand-kernel weight of common wheat (Triticum aestivum L.) in the Huang-huai wheat-growing region of China. Journal of Plant Biology and Crop Research 2(1):1012.

Liu Y, Wang R, Hu Y-G, Chen J (2018). Genome-wide linkage mapping of quantitative trait loci for late-season physiological and agronomic traits in spring wheat under irrigated conditions. Agronomy 8:60. https://doi.org/10.3390/agronomy8050060

Ma J, Zhang H, Li S, Zou Y, Li T, Liu J, ... Lan X (2019). Identification of quantitative trait loci for kernel traits in a wheat cultivar Chuannong16. BMC Genetics 20:77. https://doi.org/10.1186/s12863-019-0782-4

Maphosa L, Langridge P, Taylor H, Parent B, Emebiri LC, Kuchel H, ... Mather DE (2014). Genetic control of grain yield and grain physical characteristics in a bread wheat population grown under a range of environmental conditions. Theoretical and Applied Genetics 127:1607-1624. https://doi.org/10.1007/s00122-014-2322-y

Mochida K, Tsujimoto H (2001). Production of wheat doubled haploids by pollination with Job's tears (Coixlachrymajobi L.). Journal of Heredity 92(1):81-83. https://doi.org/10.1093/jhered/92.1.81

Mohammadi M, Sharifi P, Karimizadeh R, Shefazadeh MK (2012). Relationships between grain yield and yield components in bread wheat under different water availability (dryland and supplemental irrigation conditions). Notulae Botanicae Horti Agrobotanici Cluj-Napoca 40(1):195-200. https://doi.org/10.15835/nbha4017350

Niu Z, Jiang A, Hammad WA, Oladzadabbasabadi A, Xu SS, Mergoum M, Elias EM (2014). Review of doubled haploid production in durum and common wheat through wheat x maize hybridization. Plant Breeding 133:313-320. https://doi.org/10.1111/pbr.12162

Patial M, Pal D, Thakur A, Bana RS, Patial S (2019). Doubled haploidy techniques in wheat (Triticum aestivum L.): An overview. Proceedings of the National Academy of Sciences, India Section B: Biological Sciences 89:27-41. https://doi.org/10.1007/s40011-017-0870-Z

Petrovic S, Worland AJ (1988). The use of reciprocal monosomic analysis to detect variation between certain chromosomes of wheat varieties Bersee and Sava. Proc $7^{\text {th }}$ Int. Wheat Genetics Symp. Cambridge, England pp 629-633. 
Purchase JL, Hatting H, van Deventer CS (2000). Genotype $\times$ environment interaction of winter wheat (Triticum aestivum L.) in South Africa: II. Stability analysis of yield performance. South African Journal of Plant and Soil 17:101-107. https://doi:10.1080/02571862.2000.10634878

Ramya P, Chaubal A, Kulkarni K, Gupta L, Kadoo N, Dhaliwal HS, ... Gupt V (2010). QTL mapping of 1000-kernel weight, kernel length, and kernel width in bread wheat (Triticum aestivum L.). Journal of Applied Genetics 51(4):421-429. https://doi.org/10.1007/BF03208872

Ren J, Wu P, Trampe B, Tian X, Lubberstedt T, Chen S (2017). Novel technologies in doubled haploid line development. Plant Biotechnology Journal 15:1361-1370. https://doi.org/10.1111/pbi.12805

RebetzkeGJ, Condon AG, Farquhar GD, Appels R, Richards RA (2008). Quantitative trait loci for carbon isotope discrimination are repeatable across environments and wheat mapping populations. Theoretical and Applied Genetics 118:123-137. https://doi.org/10.1007/s00122-008-0882-4

Sharma RC, Rajaram S, Alikulov S, Ziyaev Z, Hazratkulova S, Khodarahami M, ... Mosaad M (2013). Improved winter wheat germplasm for Central and West Asia. Euphytica 190:19-31. https://doi:10.1007/s10681-012-0732-y

Sharma RC, Morgounov A, Akin B, Bespalova L, Lang L, Litvinenko M, ... Braun HJ (2014). Winter wheastern European regional yield trial: Identification of superior genotypes and characterization of environments. Crop Science 54:1-12. https://doi.org/10.2135/cropsci2014.01.0028

Simmonds J, Scott P, Everington-Waite M, Turner AS, Brinron J, Korzun V, ... Uauy C (2014). Identification and independent validation of a stable yield and thousand grain weight QTL on chromosome 6A of hexaploid wheat. (Triticum aestivum L.). BMC Plant Biology 14:191. https://doi.org/10.1186/s12870-014-0191-9

Snape JW, Law CN, Parker BB, Worland AJ (1985). Genetical analysis of chromosome 5A of wheat and its influence on important agronomic characters. Theoretical and Applied Genetics 71:518-526. https://doi.org/10.1007/BF00251199

Tayyar S (2010). Variation in grain yield and quality of Romanian bread wheat varieties compared to local varieties in north-western Turkey. Romanian Biotechnology Letters 15:5189-5196.

Wang L, Ge H, Hao C, Dong Y, Zhang X (2012). Identifying loci influencing 1,000-kernel weight in wheat by microsatellite screening for evidence of selection during breeding. PloS One 7:e29432. https://doi.org/10.1371/journal.pone.0029432

Wu X, Wang Z, Chang X, Jing R (2010). Genetic dissection of the developmental behaviours of plant height in wheat under diverse water regimes. Journal of Experimental Botany 61(11):2923-2937. https://doi.org/10.1093/jxb/erq117

Zhang K, Tian J, Zhao L, Liu B, Chen G (2009). Detection of quantitative trait loci for heading date based on the doubled haploid progeny of two elite Chinese wheat cultivars. Genetica 135:257-265. https://doi.org/10.1007/s10709-008-9274-6

Zhang L, Xu X, Zhao C, Shan F, Yuan S, Sun H (2011). QTL analysis of plant height based on doubled haploid (DH) population derived from PTSMS wheat. Molecular Plant Breeding 2(13). https://doi.org/10.5376/mpb.2011.02.0013

Zhang D, Hao C, Wang L, Zhang X (2012). Identifying loci influencing grain number by microsatellite screening in bread wheat (Triticum aestivum L.). Planta 236:1507-1517. https://doi.org/10.1007/s00425-012-1708-9

Zhang XY, Deng ZY, Wang HR, Li JF, Tian JC (2014). Unconditional and conditional QTL analysis of kernel weight related traits in wheat (Triticum aestivum L.) in multiple genetic backgrounds. Genetica 142:371-379. https://doi:10.1007/s10709-014-9781-6

Zhang G, Wang Y, Guo Y, Zhao Y, Kong F, Li S (2015). Characterization and mapping of QTLs on chromosome 2D for grain size and yield traits using a mutant line induced by EMS in wheat. The Crop Journal 3:135-144. https://doi.org/10.1016/j.cj.2014.11.002

Zhang H, Chen J, Li R, Deng Z, Zhang K, Liu B, Tian J (2016). Conditional QTL mapping of three yield components in common wheat (Triticum aestivum L.). The Crop Journal 4(3):220-228. https://doi.org/10.1016/j.cj.2016.01.00

Xie Q, Mayes S, Sparkes DL (2015). Carpel size, grain filling, and morphology determine individual grain weight in wheat. Journal of Experimental Botany 66(21):6715-6730. https://doi.org/10.1093/jxb/erv378 

OPEN ACCESS

(c) (1)

The journal offers free, immediate, and unrestricted access to peer-reviewed research and scholarly work. Users are allowed to read, download, copy, distribute, print, search, or link to the full texts of the articles, or use them for any other lawful purpose, without asking prior permission from the publisher or the author.

License -Articles published in Notulae Botanicae Horti Agrobotanici Cluj-Napoca are Open-Access, distributed under the terms and conditions of the Creative Commons Attribution (CC BY 4.0) License.

(C) Articles by the authors; UASVM, Cluj-Napoca, Romania. The journal allows the author(s) to hold the copyright/to retain publishing rights without restriction. 